\title{
Gliclazide may have an antiapoptotic effect related to its antioxidant properties in human normal and cancer cells
}

\author{
Agnieszka Sliwinska $\cdot$ Aneta Rogalska • \\ Marzena Szwed • Jacek Kasznicki • \\ Zofia Jozwiak · Jozef Drzewoski
}

Received: 6 June 2011/Accepted: 3 December 2011/Published online: 20 December 2011

(C) The Author(s) 2011. This article is published with open access at Springerlink.com

\begin{abstract}
Experimental and clinical studies suggest that gliclazide may protect pancreatic $\beta$-cells from apoptosis induced by an oxidative stress. However, the precise mechanism(s) of this action are not fully understood and requires further clarification. Therefore, using human normal and cancer cells we examined whether the anti-apoptotic effects of this sulfonylurea is due to its free radical scavenger properties. Hydrogen peroxide $\left(\mathrm{H}_{2} \mathrm{O}_{2}\right)$ as a model trigger of oxidative stress was used to induce cell death. Our experiments were performed on human normal cell line (human umbilical vein endothelial cell line, HUVEC-c) and human cancer cell lines (human mammary gland cell line, Hs578T; human pancreatic duct epithelioid carcinoma cell line, PANC-1). To assess the effect of gliclazide the cells were pretreated with the drug. The 3-[4,5-dimethylthiazol-2-yl]-2,5diphenyltetrazolium bromide assay was employed to measure the impact of gliclazide on cell viability. Generation of reactive oxygen species, mitochondrial membrane potential $\left(\Delta \Psi_{\mathrm{m}}\right)$, and intracellular $\mathrm{Ca}^{2+}$ concentration $\left[\mathrm{Ca}^{2+}\right]$ were monitored. Furthermore, the morphological changes associated with apoptosis were determined using double staining with Hoechst 33258-propidium iodide (PI). Gliclazide
\end{abstract}

A. Sliwinska · J. Kasznicki · J. Drzewoski $(\bowtie)$

Department of Internal Medicine, Diabetology and Clinical

Pharmacology, Medical University of Lodz, Parzeczewska 35,

Zgierz, 95-100 Lodz, Poland

e-mail: jdrzew@poczta.onet.pl

A. Rogalska $\cdot$ M. Szwed $\cdot$ Z. Jozwiak

Department of Thermobiology, University of Lodz,

Banacha12/16, 90-237 Lodz, Poland

Present Address:

A. Rogalska $\cdot$ M. Szwed $\cdot$ Z. Jozwiak

Department of Thermobiology, University of Lodz,

Pomorska 141/143, 90-237 Lodz, Poland protects the tested cells from $\mathrm{H}_{2} \mathrm{O}_{2}$-induced cell death most likely throughout the inhibition of ROS production. Moreover, the drug restored loss of $\Delta \Psi_{\mathrm{m}}$ and diminished intracellular $\left[\mathrm{Ca}^{2+}\right]$ evoked by $\mathrm{H}_{2} \mathrm{O}_{2}$. Double staining with Hoechst 33258-PI revealed that pre-treatment with gliclazide diminished the number of apoptotic cells. Our findings indicate that gliclazide may protect both normal and cancer human cells against apoptosis induced by $\mathrm{H}_{2} \mathrm{O}_{2}$. It appears that the anti-apoptotic effect of the drug is most likely associated with reduction of oxidative stress.

Keywords Apoptosis - Gliclazide - Reactive oxygen species $\cdot$ Mitochondrial membrane potential $\cdot$ Calcium

\section{Introduction}

Prospective clinical studies and autopsy studies show significant reduction of $\beta$-cell function and mass, respectively, in people with type 2 diabetes mellitus (T2DM) [1]. Several factors including hyperglycemia, hyperinsulinemia, hyperlipidemia, low-grade inflammation, and deposition of islet amyloid polypeptide in human pancreas have been proposed to account for this defect in T2DM [2-4]. Chronic hyperglycemia leads to an increased generation of reactive oxygen species (ROS), oxidative stress, and endoplasmic reticulum stress in a variety of cells. In comparison with many other cell types, the $\beta$-cells may be at exceptionally high risk of oxidative damage and an increased sensitivity for apoptosis [5, 6].

Apart from a fundamental role of mitochondrial electron transport chain in ROS overproduction, additional sources of ROS may increase oxidative stress in diabetes including glucose autoxidation, protein kinase $\mathrm{C}$ activation, methylglyoxal formation and glycation, hexosamine metabolism, and sorbitol formation $[2,4,7,8]$. Recently published data 
indicate, that excessive concentration of ROS in diabetes is responsible for the activation of several intracellular signalling pathways, that may affect cell function and structure, increasing the risk of apoptosis [5, 6].

Gliclazide - a second-generation sulphonylurea-is commonly used for the treatment of T2DM. The drug act by stimulating insulin release from the pancreatic $\beta$-cells to lower blood glucose. The insulin secretion is triggered by binding of gliclazide to a specific $\mathrm{K}^{+}$sulfonylurea receptor subtype of ATP-sensitive potassium channels at the level of $\beta$-cells plasma membrane (sulfonylurea receptor 1 , SUR1), which leads to its closure and subsequent opening of the calcium channels and activation of an effector system of insulin release [9]. The binding of gliclazide to SUR1 is rapidly reversible in contrast to other sulphonylureas (e.g. glibenclamide), that exhibit prolonged binding to SUR1. Besides its hypoglycemic effect, gliclazide has been found to possess extra - pancreatic and antioxidant properties. It appears, that antioxidant activities are independent of any influence on glycemic control [10, 11].

It is of concern, that the long-term use of sulphonylureas, especially glibenclamide, may cause $\beta$-cells dysfunction and apoptosis [1]. However, the mechanism(s) of this serious, unwanted effect is unclear and several explanations have been proposed. One of them is an oxidative stress that in people with T2DM is not only related to chronic hyperglycemia but, it is also suggested that insulin secretagogues may directly increase ROS generation and cause an oxidative stress related in $\beta$-cell apoptosis [12]. As a consequence of ROS overproduction and its damaging action, b-cell mass and secretory function in T2DM patients treated with sulfonylurea may progressively decline. Insufficient level of insulin in the circulation is responsible for uncontroled hyperglycemia and hyperlipidemia, which in turn cause $\beta$-cell damage and induce apoptosis $[13,14]$. According to Rustenberg et al. this situation may create a vicious circle, with the improvement of metabolic control being achieved at the expense of an accelerated loss of beta cell mass [8] .

Interestingly enough, it has recently been found that gliclazide prevented mice, rat and human pancreatic $\beta$-cells and human endothelial cells from apoptosis [15-19]. It is suggested that this action of the drug is most likely associated with its free radical scavenging properties [20]. However, anti-apoptotic action of gliclazide in other types of cells, especially cancer cells, has not been explored sufficiently. Therefore, the aim of our study was to check whether gliclazide has also ability to prevent human normal (HUVEC-c) and two cancer cell lines (PANC-1 and Hs578T) from apoptosis induced by an oxidative stress. The HUVEC-c cell line as a one of type of human normal endothelial cells has not been explored for this purpose. We believe that PANC-1 and Hs578T cell lines are good candidates for our study as examples of the most common T2DM associated cancers.

\section{Materials and methods}

\section{Chemicals}

Hydrogen peroxide $\left(\mathrm{H}_{2} \mathrm{O}_{2}\right)$ and gliclazide were obtained from Sigma Chemicals (St. Louis, USA). Kaighn's modification of Ham's F-12 medium (F-12K), Dulbecco's modified Eagle's medium (DMEM) and fetal bovine serum was supplied by American Type Culture Collection (ATCC) (Rockville, MD, USA). Trypsin-EDTA, penicillin/streptomycin, $2^{\prime}, 7^{\prime}$-dichlorodihydrofluorescein diacetate (DCFH2-DA) and 5,5',6,6'-tetrachloro-1, $1^{\prime}, 3,3^{\prime}$ - tetraethylbenzimidazolcarbocyanine iodide (JC-1) were purchased from Sigma. Fluo-4 NW Calcium Assay Kits were obtained from Molecular Probes (Eugene, USA). All other chemicals and solvents were of high analytical grade and were obtained from Sigma or POCH S.A. (Gliwice, Poland).

\section{Cell culture and treatment}

The normal cell line (human umbilical vein endothelial cell line-HUVEC-c), and cancer cell lines (pancreatic duct epithelioid carcinoma cell line-PANC-1 and mammary gland cell line-Hs578T) were purchased from ATCC. PANC-1 cell strain is derived from an epithelioid carcinoma of pancreatic duct of 56 year old Caucasian male. Chromosome studies indicate a modal number of 63 with 3 distinct marker chromosomes and a small ring chromosome. This is a hypertriploid cell line. The Hs $578 \mathrm{~T}$ cell strain is derived from the breast carcinoma of 74 year old Caucasian female. Cytogenetic analysis revealed that Hs578T cell line is a hypotriploid with a modal chromosome number of 59. This cell line does not express estrogen receptor. All cell lines were grown as a monolayer in standard conditions: $37^{\circ} \mathrm{C}, 100 \%$ humidity, the atmosphere being $5 \% \mathrm{CO}_{2}$ and $95 \%$ air with appropriate growth medium: (1) HUVEC-c cell line-F-12K medium supplemented with $0.1 \mathrm{mg} / \mathrm{ml}$ heparin and $0.05 \mathrm{mg} / \mathrm{ml}$ endothelial cell growth supplement, (2) PANC-1 cell line-DMEM, and (3) Hs578T cell lineDMEM supplemented with $0.01 \mathrm{mg} / \mathrm{ml}$ bovine insulin. Complete growth media were supplemented with $10 \%$ fetal bovine serum, penicillin $(10 \mathrm{U} / \mathrm{ml})$ and streptomycin $(50 \mu \mathrm{g} / \mathrm{ml})$. In all experiments cells in logarithmic phase of growth were used. The cells were monitored periodically for mycoplasma contamination. Cultured cells were removed by trypsinization, resuspended in fresh medium, centrifuged for $5 \mathrm{~min}$ at $200 \times g$ and plated into 96-well plates at the density of $10^{5}$ cells $/ \mathrm{ml}\left(10^{4}\right.$ cells/well $)$ for 3-[4,5-dimethylthiazol-2-yl]-2,5-diphenyltetrazolium bromide (MTT), ROS, mitochondrial membrane potential assays or on petri dishes for morphological examination and at the density of $3 \times 10^{4}$ cells for calcium assay according to the manufacture's protocol. After $24 \mathrm{~h}$ (time 
necessary to ensure, that the cells were in the exponential growth phase) different concentrations of $\mathrm{H}_{2} \mathrm{O}_{2}$ were added to the appropriate microplate wells or Petri dishes and the cells were incubated in a $\mathrm{CO}_{2}$ incubator for different period of time $(2-72 \mathrm{~h})$ depending on the assessment method.

In some experiments cells were pre-incubated with the $3 \mathrm{mM} \mathrm{N}$-acetylcysteine (NAC) or different concentrations of gliclazide $(5-50 \mu \mathrm{M})$ for $1 \mathrm{~h}$, then $\mathrm{H}_{2} \mathrm{O}_{2}$ at the appropriate subtoxic concentration $(50,100,200 \mu \mathrm{M})$ was added and incubation was continued for the required period of time under the same conditions. After pre-treatment with NAC or gliclazide the media were replaced with fresh ones without NAC or gliclazide. Control cells were treated with a corresponding volume of medium (instead of $\mathrm{H}_{2} \mathrm{O}_{2}$ or antioxidants) according to the same schedule. NAC was used as a control agent for gliclazide.

\section{Cytotoxicity assays}

The cytotoxicity of $\mathrm{H}_{2} \mathrm{O}_{2}$ in human tumor and normal cell lines was measured by a standard microplate MTT colorimetric method [21]. For this purpose $10^{4}$ cells in $0.1 \mathrm{ml}$ culture medium were seeded to each well. After $24 \mathrm{~h}$, $0.05 \mathrm{ml} \mathrm{H}_{2} \mathrm{O}_{2}$ in different concentrations $(50-600 \mu \mathrm{M})$ was added to appropriate wells, and cells were incubated for 24 , 48 or $72 \mathrm{~h}$. After incubation, $50 \mu \mathrm{l} \mathrm{MTT}$ at the final concentration of $6 \times 10^{-3} \mathrm{M}$ in PBS was added to each well and the microplates were incubated in a $\mathrm{CO}_{2}$ incubator for $3 \mathrm{~h}$. After aspiration of the culture medium, the obtained formazan crystals were dissolved in $100 \mu$ dimethyl sulfoxide (DMSO), the plates were mechanically agitated for $1 \mathrm{~min}$, and absorbance at $570 \mathrm{~nm}$ was measured with a microplate reader (Awareness Technology Inc., USA). Cytotoxicity of the $\mathrm{H}_{2} \mathrm{O}_{2}$ was expressed as $\mathrm{IC}_{50}$ value, which is the concentration of compound that reduces cell viability by $50 \%$ relative to the control (untreated cells).

In the experiments with antioxidant, the cells were preincubated with NAC $(3 \mathrm{mM})$ or gliclazide $(5-50 \mu \mathrm{M})$ and then treated with 50,100 or $200 \mu \mathrm{M}$ of $\mathrm{H}_{2} \mathrm{O}_{2}$ for 24,48 or $72 \mathrm{~h}$. The relative number of viable cells was determined by comparing the absorbance of the treated cells with the corresponding absorbance of untreated (control) cells taken as $100 \%$.

\section{Determination of ROS level}

Intracellular ROS production was determined directly in cell monolayers in black 96-well flat-bottom microtiter plates using a Fluoroskan Ascent FL microplate reader (Labsystems, Sweden). Cells in complete medium were incubated with $50-200 \mu \mathrm{M}$ of $\mathrm{H}_{2} \mathrm{O}_{2}$ for 2,4 or $24 \mathrm{~h}$ in the presence or absence of the antioxidants ( $3 \mathrm{mM} \mathrm{NAC}$, gliclazide: $5-50 \mu \mathrm{M}$ ). To measure the production of ROS, cells were treated with $5 \mu \mathrm{M}$ DCFH2-DA at $37^{\circ} \mathrm{C}$ for $30 \mathrm{~min}$ and the fluorescence of DCF was measured at $530 \mathrm{~nm}$ after excitation at $485 \mathrm{~nm}$ (DCFH2-DA after deacetylation to DCFH2 is oxidized intracellularly to its fluorescent derivative DCF). Assays were performed in modified Hank's buffered salt solution (HBSS) $(140 \mathrm{mM}$ $\mathrm{NaCl}, 5 \mathrm{mM} \mathrm{KCl}, 0.8 \mathrm{mM} \mathrm{MgCl} 2,1.8 \mathrm{mM} \mathrm{CaCl}_{2}, 1 \mathrm{mM}$ $\mathrm{Na}_{2} \mathrm{HPO}_{4}, 10 \mathrm{mM}$ HEPES and $1 \%$ glucose, $\mathrm{pH}$ 7.0).

\section{Mitochondrial membrane potential $\left(\Delta \Psi_{\mathrm{m}}\right)$}

Cells were seeded in $0.1 \mathrm{ml}$ culture medium into black 96-well titration microplates. After $24 \mathrm{~h}, 0.05 \mathrm{ml} \mathrm{H}_{2} \mathrm{O}_{2}$ (50-200 $\mu \mathrm{M})$ or an uncoupling mitochondrial agent chlorophenylhydrazone (CCCP) in various concentrations $(0.01-10 \mu \mathrm{M})$ was added to appropriate wells. The cells were incubated with $\mathrm{H}_{2} \mathrm{O}_{2}$ and CCCP for 2, 4 or $24 \mathrm{~h}$. At the end of $\mathrm{H}_{2} \mathrm{O}_{2}$ or CCCP treatment, the medium was removed and the cells were incubated with $5 \mu \mathrm{M} \mathrm{JC}-1$ in HBSS for $30 \mathrm{~min}$, at $37^{\circ} \mathrm{C}$, in the dark. Then the fluorescence of both JC-1 monomers and dimers was measured on a Fluoroskan Ascent FL microplate reader (Labsystems, Sweden) using filter pairs of $530 \mathrm{~nm} / 590 \mathrm{~nm}$ (dimers) and $485 \mathrm{~nm} / 538 \mathrm{~nm}$ (monomers). JC-1 is a fluorescent carbocyanine dye, which accumulates in the mitochondrial membrane in two forms (monomers or dimers), depending on mitochondrial membrane potential. JC-1 monomers show maximum fluorescence excitation and emission at 485 and $538 \mathrm{~nm}$ wavelengths, respectively. Negative potential of the inner mitochondrial membrane facilitates the formation of dye aggregates, which results in the shift of JC-1 monomer fluorescence towards red light (from $\lambda_{\mathrm{ex}}=530 \mathrm{~nm}$ to $\lambda_{\mathrm{em}}=590 \mathrm{~nm}$ ) [22]. Thus, the measurement of the JC-1 dimer to monomer fluorescence ratio is a convenient and reliable method for estimation of changes in mitochondrial membrane potential. Prior to fluorescence measurements and taking pictures, the cells were washed twice with HBSS to remove the dye, which could be adsorbed into the microplate well plastic and disturb the measurements. The results in the figures are shown as a ratio of dimer to monomer fluorescence in relation to the control fluorescence ratio, assumed to be $100 \%$. As a positive control for the dissipation of $\Delta \Psi_{\mathrm{m}}$, cells were incubated with an uncoupling mitochondrial agent CCCP.

The cells presented in the pictures in Fig. 5 were preincubated with $25 \mu \mathrm{M}$ gliclazide or $3 \mathrm{mM}$ NAC for $1 \mathrm{~h}$, then $\mathrm{H}_{2} \mathrm{O}_{2}(200 \mu \mathrm{M})$ was added and incubation was continued for the next $4 \mathrm{~h}$. JC-1 fluorescence was photographed immediately after drug treatment. 
Monitoring of apoptosis and necrosis

The appearance of apoptotic and necrotic cells was monitored by double staining with Hoechst 33258 and propidium iodide using a fluorescence microscopy (Olympus IX70, Japan; magnification $400 \times$ ). After 24,48 or $72 \mathrm{~h}$ treatment of cells with $200 \mu \mathrm{M}$ of $\mathrm{H}_{2} \mathrm{O}_{2}$, the cells were removed from the culture dishes by trypsinization, centrifuged and suspended in PBS at the concentration $10^{6}$ cells/ ml. $1 \mu$ Hoechst $33258(0.13 \mathrm{mM})$ and $1 \mu \mathrm{l} \mathrm{PI}(0.23 \mathrm{mM})$ were added to $100 \mu \mathrm{l}$ of cell suspension. After $10 \mathrm{~min}$ of incubation at room temperature in the dark, the cells were dropped onto microscopic slides and examined. When antioxidants were included the cells were firstly incubated with $3 \mathrm{mM}$ NAC or $25 \mu \mathrm{M}$ gliclazide for $1 \mathrm{~h}$, and then with a $\mathrm{H}_{2} \mathrm{O}_{2}$ for additional 24,48 or $72 \mathrm{~h}$. The cells were classified on the basis of their morphological and staining characteristics as: live (mate blue fluorescence), early apoptotic cells (intensive bright blue fluorescence), late apoptotic cells (blue-violet fluorescence) and necrotic (red fluorescence) [23]. Representative areas of cells stained at $48 \mathrm{~h}$ of were chosen for documentation.

Intracellular calcium measurement

Control and $\mathrm{H}_{2} \mathrm{O}_{2}$ treated cells were seeded into a 96-well plate $\left(3 \times 10^{4}\right.$ cells in $0.2 \mathrm{ml}$ culture medium per well). After $24 \mathrm{~h}$ the cells were treated with $\mathrm{H}_{2} \mathrm{O}_{2}(50-200 \mu \mathrm{M})$ for $4,24,48$ or $72 \mathrm{~h}$. In experiments with antioxidants, cells were preincubated with $3 \mathrm{mM}$ NAC or $5-50 \mu \mathrm{M}$ gliclazide for $1 \mathrm{~h}$, then $\mathrm{H}_{2} \mathrm{O}_{2}$ was added and incubation was continued for another 4, 24, 48 or $72 \mathrm{~h}$. At the end of incubations the medium was removed in order to eliminate sources of baseline fluorescence (the cells were washed twice with PBS). Subsequently cells were incubated with dye loading solution (Fluo-4 NW dye, probenecid, assay buffer-1 $1 \times$ HBSS, $20 \mathrm{mM}$ HEPES), which were processed according to the Fluo-4 NW Calcium Assay Kit protocol supplied by the manufacturer (Molecular Probes) and incubated for $30 \mathrm{~min}$ in the dark at $37^{\circ} \mathrm{C}$, and then for another $30 \mathrm{~min}$ at the room temperature. The measurement was done on Fluoroskan Ascent FL microplate reader (Labsystems, Sweden) using $494 \mathrm{~nm}$ excitation and $516 \mathrm{~nm}$ emission wavelengths.
Statistical analysis

Data are expressed as a mean \pm SD. Analysis of ANOVA variance with a Tukey post hoc test was used for multiple comparisons. All statistics were calculated using the STATISTICA program (StatSoft, Tulsa, OK, USA). A $P$ value of $<0.05$ was considered significant.

\section{Results}

Cytotoxicity studies

The cytotoxic activity of hydrogen peroxide was determined by the MTT test after 24,48 and $72 \mathrm{~h}$ (Table 1). The highest cytotoxicity of $\mathrm{H}_{2} \mathrm{O}_{2}$ was observed after $72 \mathrm{~h}$ of incubation. The $\mathrm{IC}_{50}$ values of $\mathrm{H}_{2} \mathrm{O}_{2}$ after $72 \mathrm{~h}$ of treatment were $343 \mu \mathrm{M}, 433 \mu \mathrm{M}$ and $482 \mu \mathrm{M}$ for normal cell line (HUVEC-c), breast (Hs578T) and pancreatic cancer cell line (PANC-1), respectively (Table 1) $(P \leq 0.005)$. Thus, the Hs578T cells and PANC-1 cells were about 1.3 and 1.4 fold more resistant to the $\mathrm{H}_{2} \mathrm{O}_{2}$ than the normal cells (HUVEC-c). To discriminate the differences between early and the late effects of $\mathrm{H}_{2} \mathrm{O}_{2}$ action, the investigated cell lines were exposed to increasing hydrogen peroxide concentrations for 24,48 and $72 \mathrm{~h}$. The results revealed the marked differences between 24 and $72 \mathrm{~h}$ of incubation. As shown in Fig. 1, $24 \mathrm{~h}$ of incubation with toxic $(600 \mu \mathrm{M})$ concentration of $\mathrm{H}_{2} \mathrm{O}_{2}$ reduced a viability of tested cells to about $50 \%$ in relation to $72 \mathrm{~h}$ exposure (30\% of control) $(P \leq 0.05)$. A comparison of cell viability after 24 and $72 \mathrm{~h}$ treatment with $\mathrm{H}_{2} \mathrm{O}_{2}$ revealed that the duration of treatment is an important factor for $\mathrm{H}_{2} \mathrm{O}_{2}$ cytotoxic effects. Experimental data indicate that nontoxic concentration of $\mathrm{H}_{2} \mathrm{O}_{2}$ $(50-200 \mu \mathrm{M})$ should be used to explore the effect of gliclazide on early apoptotic changes [15, 19]. Table 2 presents, that pre-treatment of all type of cells with NAC $(3 \mathrm{mM})$ or gliclazide $(5-50 \mu \mathrm{M})$ followed by $\mathrm{H}_{2} \mathrm{O}_{2}$ $(50 \mu \mathrm{M})$ treatment improved cell viability by about $100 \%$. Gliclazide used in the entire range of concentrations increased viability after exposure to hydrogen peroxide $(200 \mu \mathrm{M})$ to $90 \%$ regardless of the type of cell line.
Table 1 Cytotoxicity of $\mathrm{H}_{2} \mathrm{O}_{2}$ in HUVEC-c, Hs578T and PANC-1 cell lines

The values are the mean \pm SD of 3-4 independent experiments $* P<0.005$

\begin{tabular}{lccc}
\hline $\mathrm{IC}_{50}[\mu \mathrm{M}]$ values determined by the MTT test & & \\
\hline Cell line & $24 \mathrm{~h}$ & $48 \mathrm{~h}$ & $72 \mathrm{~h}$ \\
\hline HUVEC-c & $885.11 \pm 0.011^{*}$ & $467.73 \pm 0.016^{*}$ & $343.55 \pm 0.012^{*}$ \\
Hs578T & $641.21 \pm 0.009^{*}$ & $523.60 \pm 0.019^{*}$ & $433.51 \pm 0.013^{*}$ \\
PANC-1 & $1086.42 \pm 0.014^{*}$ & $770.90 \pm 0.022^{*}$ & $481.95 \pm 0.021^{*}$ \\
\hline
\end{tabular}



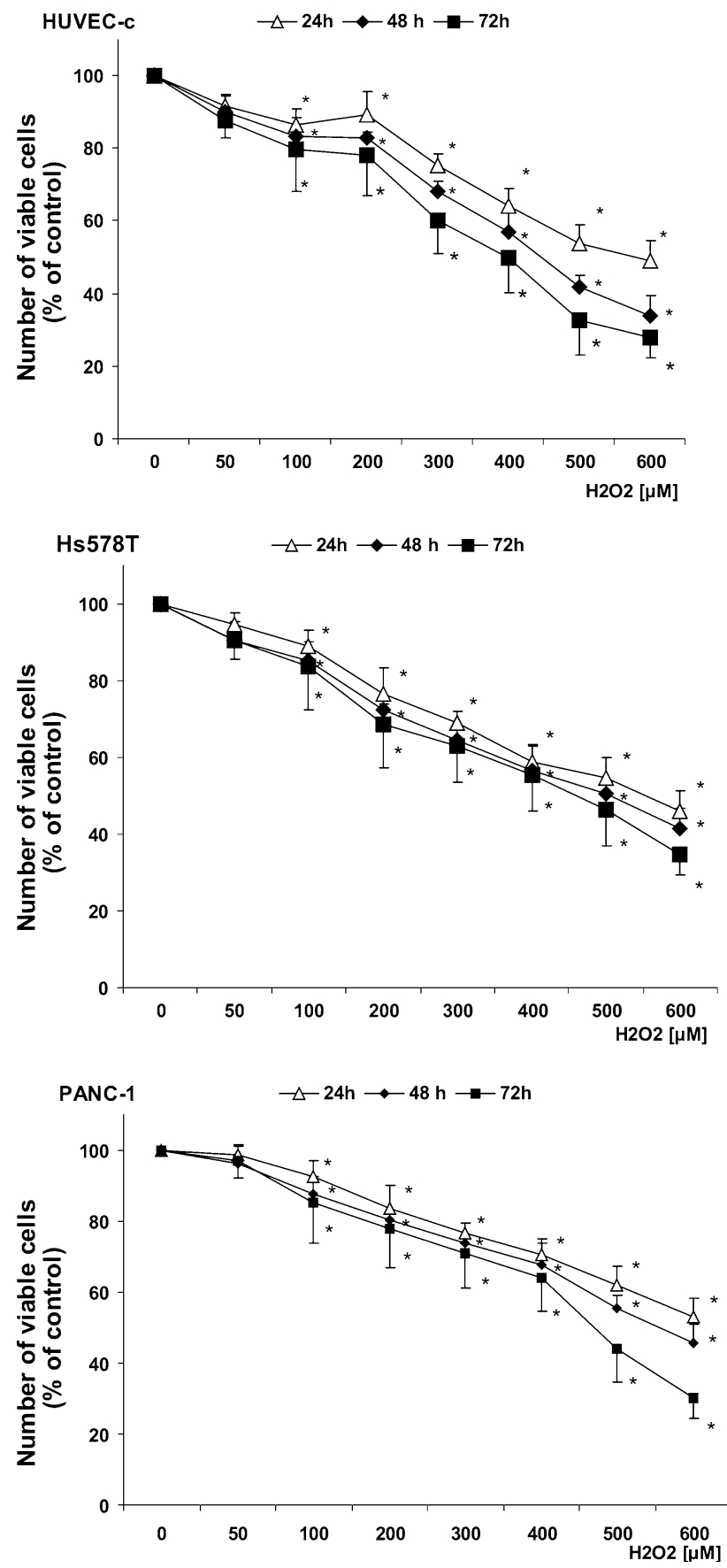

Fig. 1 Number of viable HUVEC-c, Hs578T and PANC-1 cells, The cells were treated with $\mathrm{H}_{2} \mathrm{O}_{2}(50-600 \mu \mathrm{M})$ for 24,48 and $72 \mathrm{~h}$, At the end of treatment period MTT was added and cells were incubated for an additional $3 \mathrm{~h}$. Formazan crystals were dissolved in DMSO and absorbance at $570 \mathrm{~nm}$ was measured with a microplate reader. Data are the mean $\pm \mathrm{SD}$ of $3-4$ independent experiments. $* P<0.05$ significant differences between drugs treated and untreated, control cells (taken as $100 \%$ )

\section{ROS detection}

The generation of ROS was measured using the DCFH2DA dye. It is well documented that long-term incubation with $\mathrm{H}_{2} \mathrm{O}_{2}$ (up to $72 \mathrm{~h}$ ) may result in additional generation of ROS due to its reaction with transient metals present in medium (via Fenton reaction) and release of cytochrome c which catalyzes DCFH2-DA oxidation [24]. Thus, in order to determine ROS generation exclusively for $\mathrm{H}_{2} \mathrm{O}_{2}$ we decided to measure the level of ROS at 2, 4 and $24 \mathrm{~h}$. Changes in ROS level after $\mathrm{H}_{2} \mathrm{O}_{2}$ treatment are shown in Fig. 2. In all three cell lines, a gradual increase of DCF fluorescence with the increasing concentrations of $\mathrm{H}_{2} \mathrm{O}_{2}$ was observed at 2,4 and $24 \mathrm{~h}$ after the treatment. The kinetics of ROS formation, in relation to time of incubation was dependent on the $\mathrm{H}_{2} \mathrm{O}_{2}$ concentration and the type of cell line. At $24 \mathrm{~h}$ of incubation with $\mathrm{H}_{2} \mathrm{O}_{2}(200 \mu \mathrm{M})$, the level of ROS in Hs578T and HUVEC-c cells increased 143 and $167 \%$, respectively $(P \leq 0.05)$. Generation of ROS did not correlate with the sensitivity of cells to hydrogen peroxide. The level of ROS in PANC-1 cells was similar to HUVEC-c cells and did not exceed 139\% $(P \leq 0.05)$. To confirm whether ROS are the mediator for $\mathrm{H}_{2} \mathrm{O}_{2}$ induced apoptosis, the cells were treated with antioxidants. The amounts of ROS were markedly reduced by NAC and gliclazide. Our results showed that $\mathrm{H}_{2} \mathrm{O}_{2}$ increased the level of ROS in time-dependent manner both in normal and cancer cells, and pretreatment with NAC or gliclazide efficiently protected these cells against ROS generation. These results confirm an antioxidant property of gliclazide.

Mitochondrial membrane potential $\left(\Delta \Psi_{\mathrm{m}}\right)$

In this study, normal HUVEC-c and cancer cells: Hs578T and PANC-1 were stained with a fluorogenic probe JC-1 to detect changes of their mitochondrial membrane potential after the treatment with $\mathrm{H}_{2} \mathrm{O}_{2}$. JC-1 has the unique property of forming red fluorescent aggregates locally and spontaneously under high mitochondrial potential, whereas the monomeric form, prevalent in cells with low $\Delta \Psi_{\mathrm{m}}$, fluorescens in green. Thus, the changes of the ratio of red/green fluorescence reflect the variation of $\Delta \Psi \mathrm{m}$. ROS are responsible for dissipation of mitochondrial potential thus, it is reasonable to measure mitochondrial membrane potential at the same time points as determination of the level of ROS. Images of staining with a fluorogenic probe JC- 1 tested cell lines at $4 \mathrm{~h}$ after treatment with $200 \mu \mathrm{M}$ of $\mathrm{H}_{2} \mathrm{O}_{2}$ in the presence or absence of antioxidants are presented in Fig. 3 .

Figure 4 shows the accumulation of JC- 1 within the active mitochondria of the investigated cells after exposure to $\mathrm{H}_{2} \mathrm{O}_{2}$. Treatment of cells with increasing concentrations of $\mathrm{H}_{2} \mathrm{O}_{2}(50-200 \mu \mathrm{M})$ caused the collapse of $\Delta \Psi_{\mathrm{m}}$, as detected by the reduction of JC-1 dimer to monomer fluorescence ratio. Changes in $\Delta \Psi_{\mathrm{m}}$ were dependent on both $\mathrm{H}_{2} \mathrm{O}_{2}$ concentration and the length of incubation. The highest changes were observed at $2 \mathrm{~h}$ of $\mathrm{H}_{2} \mathrm{O}_{2}$ treatment. A $200 \mu \mathrm{M}$ concentration of $\mathrm{H}_{2} \mathrm{O}_{2}$ induced a drop in 
Table 2 Number of viable HUVEC-c, Hs578T and PANC-1 cells
The cells were preincubated with 5-50 $\mu \mathrm{M}$ gliclazide for $1 \mathrm{~h}$ at $37^{\circ} \mathrm{C}$. Then the cells were treated with 50,100 or $200 \mu \mathrm{M}$ $\mathrm{H}_{2} \mathrm{O}_{2}$ for 24,48 or, $72 \mathrm{~h}$. At the end of treatment period MTT was added and cells were then incubated for an additional $3 \mathrm{~h}$. Formazan crystals were dissolved in DMSO and absorbance at $570 \mathrm{~nm}$ was measured with a microplate reader. Data are the mean $\pm \mathrm{SD}$ of 3-4 independent experiments. $* P<0.05$ in comparison to respective control cells taken as $100 \%$. ${ }^{\#} P<0.05$ indicates significant differences between $\mathrm{H}_{2} \mathrm{O}_{2-}$ treated cells and samples preincubated with NAC or gliclazide

\begin{tabular}{|c|c|c|c|c|}
\hline \multirow[t]{2}{*}{ Treatment time (h) } & \multirow[t]{2}{*}{ Agent } & \multicolumn{3}{|c|}{ Cell line ( $\%$ of viable cells) } \\
\hline & & HUVEC-c & H578T & PANC-1 \\
\hline \multirow[t]{15}{*}{24} & $\mathrm{H}_{2} \mathrm{O}_{2}[50 \mu \mathrm{M}]$ & $91.48 \pm 2.953$ & $94.65 \pm 5.96$ & $98.43 \pm 4.52$ \\
\hline & $\mathrm{NAC}[3 \mathrm{mM}]$ & $99.78 \pm 4.67$ & $100.01 \pm 5.65$ & $98.58 \pm 5.45$ \\
\hline & 5 & $99.71 \pm 5.30$ & $102.57 \pm 1.10$ & $99.50 \pm 3.00$ \\
\hline & 25 gliclazide $[\mu \mathrm{M}]$ & $99.53 \pm 8.76$ & $99.32 \pm 5.31$ & $100.34 \pm 2.35$ \\
\hline & 50 & $99.54 \pm 5.35$ & $101.43 \pm 4.12$ & $99.03 \pm 4.20$ \\
\hline & $\mathrm{H}_{2} \mathrm{O}_{2}[100 \mu \mathrm{M}]$ & $86.50 \pm 4.245$ & $88.87 \pm 3.12$ & $92.54 \pm 7.04$ \\
\hline & $\mathrm{NAC}[3 \mathrm{mM}]$ & $102.36 \pm 5.36$ & $99.87 \pm 5.26$ & $102.65 \pm 5.87$ \\
\hline & 5 & $97.36 \pm 4.18$ & $97.53 \pm 4.90$ & $95.62 \pm 4.72$ \\
\hline & 25 gliclazide $[\mu \mathrm{M}]$ & $97.23 \pm 2.04$ & $98.67 \pm 7.71$ & $94.99 \pm 5.99$ \\
\hline & 50 & $95.16 \pm 5.52$ & $98.92 \pm 5.00$ & $93.78 \pm 5.39$ \\
\hline & $\mathrm{H}_{2} \mathrm{O}_{2}[200 \mu \mathrm{M}]$ & $89.08 \pm 6.59$ & $76.54 \pm 8.09^{*}$ & $83.65 \pm 2.45$ \\
\hline & NAC $[3 \mathrm{mM}]$ & $102.54 \pm 4.65$ & $97.36 \pm 4.56^{\#}$ & $97.45 \pm 5.12$ \\
\hline & 5 & $94.87 \pm 3.63$ & $95.43 \pm 5.24^{\#}$ & $94.89 \pm 5.78$ \\
\hline & 25 gliclazide $[\mu \mathrm{M}]$ & $93.39 \pm 4.07$ & $96.56 \pm 2.87^{\#}$ & $93.77 \pm 2.61$ \\
\hline & 50 & $95.01 \pm 4.36$ & $95.62 \pm 9.31^{\#}$ & $90.78 \pm 488$ \\
\hline \multirow[t]{15}{*}{48} & $\mathrm{H}_{2} \mathrm{O}_{2}[50 \mu \mathrm{M}]$ & $90.10 \pm 4.87$ & $90.43 \pm 4.56$ & $96.32 \pm 5.56$ \\
\hline & NAC [3 mM] & $101.27 \pm 2.93$ & $100.33 \pm 3.87$ & $100.11 \pm 4.57$ \\
\hline & 5 & $99.27 \pm 4.32$ & $99.87 \pm 3.43$ & $100.11 \pm 4.32$ \\
\hline & 25 gliclazide $[\mu \mathrm{M}]$ & $97.21 \pm 6.87$ & $98.43 \pm 4.56$ & $99.21 \pm 5.37$ \\
\hline & 50 & $98.12 \pm 2.33$ & $101.01 \pm 6.71$ & $101.33 \pm 6.71$ \\
\hline & $\mathrm{H}_{2} \mathrm{O}_{2}[100 \mu \mathrm{M}]$ & $83.45 \pm 4.89^{*}$ & $85.32 \pm 7.43$ & $87.43 \pm 4.87$ \\
\hline & NAC [3 mM] & $98.25 \pm 6.32^{\#}$ & $97.19 \pm 4.52$ & $96.12 \pm 3.33$ \\
\hline & 5 & $97.12 \pm 1.67^{\#}$ & $102.34 \pm 4.56$ & $95.27 \pm 4.34$ \\
\hline & 25 gliclazide $[\mu \mathrm{M}]$ & $98.11 \pm 2.43^{\#}$ & $99.99 \pm 4.39^{\#}$ & $96.28 \pm 3.28$ \\
\hline & 50 & $96.23 \pm 3.78^{\#}$ & $97.43 \pm 2.67^{\#}$ & $94.33 \pm 6.72$ \\
\hline & $\mathrm{H}_{2} \mathrm{O}_{2}[200 \mu \mathrm{M}]$ & $82.89 \pm 1.65$ & $72.15 \pm 2.45^{*}$ & $80.32 \pm 7.45^{*}$ \\
\hline & NAC [3 mM] & $97.34 \pm 3.12^{\#}$ & $98.11 \pm 4.18^{\#}$ & $97.11 \pm 3.12^{\#}$ \\
\hline & 5 & $93.11 \pm 4.57^{\#}$ & $94.43 \pm 9.17^{\#}$ & $90.32 \pm 2.32^{\#}$ \\
\hline & 25 gliclazide $[\mu \mathrm{M}]$ & $90.12 \pm 6.87^{\#}$ & $96.12 \pm 6.32^{\#}$ & $90.12 \pm 4.371^{\#}$ \\
\hline & 50 & $89.43 \pm 4.36^{\#}$ & $94.77 \pm 4.87^{\#}$ & $90.18 \pm 7.17^{\#}$ \\
\hline \multirow[t]{15}{*}{72} & $\mathrm{H}_{2} \mathrm{O}_{2}[50 \mu \mathrm{M}]$ & $87.87 \pm 5.01$ & $90.42 \pm 4.59$ & $97.11 \pm 1.44$ \\
\hline & NAC [3 mM] & $98.78 \pm 6.89^{\#}$ & $97.89 \pm 4.95$ & $99.89 \pm 3.89$ \\
\hline & 5 & $98.34 \pm 4.29^{\#}$ & $102.57 \pm 0.53^{\#}$ & $99.50 \pm 0.79$ \\
\hline & 25 gliclazide $[\mu \mathrm{M}]$ & $101.23 \pm 2.15^{\#}$ & $99.32 \pm 3.63$ & $100.34 \pm 2.26$ \\
\hline & 50 & $99.95 \pm 5.14^{\#}$ & $1010.41 \pm 1.70$ & $99.03 \pm 4.92$ \\
\hline & $\mathrm{H}_{2} \mathrm{O}_{2}[100 \mu \mathrm{M}]$ & $79.64 \pm 6.24^{*}$ & $83.77 \pm 6.24$ & $85.21 \pm 3.89^{*}$ \\
\hline & NAC [3 mM] & $99.98 \pm 9.08^{\#}$ & $100.89 \pm 5.89^{\#}$ & $99.98 \pm 7.58^{\#}$ \\
\hline & 5 & $88.26 \pm 9.48^{\#}$ & $87.55 \pm 7.19^{\#}$ & $85.15 \pm 3.77^{\#}$ \\
\hline & 25 gliclazide $[\mu \mathrm{M}]$ & $86.38 \pm 6.66^{\#}$ & $86.59 \pm 7.73$ & $84.50 \pm 2.73^{\#}$ \\
\hline & 50 & $88.43 \pm 5.10^{\#}$ & $87.67 \pm 5.52$ & $84.93 \pm 2.43$ \\
\hline & $\mathrm{H}_{2} \mathrm{O}_{2}[200 \mu \mathrm{M}]$ & $78.181 \pm 1.20 *$ & $68.53 \pm 6.77^{*}$ & $77.87 \pm 8.08^{*}$ \\
\hline & NAC [3 mM] & $98.67 \pm 6.98^{\#}$ & $102.67 \pm 8.43^{\#}$ & $99.78 \pm 4.76^{\#}$ \\
\hline & 5 & $94.32 \pm 4.52^{\#}$ & $93.32 \pm 5.55^{\#}$ & $90.62 \pm 0.79^{\#}$ \\
\hline & 25 gliclazide $[\mu \mathrm{M}]$ & $90.43 \pm 6.25^{\#}$ & $95.43 \pm 3.79^{\#}$ & $90.99 \pm 2.26^{\#}$ \\
\hline & 50 & $88.32 \pm 3.54^{\#}$ & $90.32 \pm 6.15^{*}$ & $89.13 \pm 4.92^{\#}$ \\
\hline
\end{tabular}



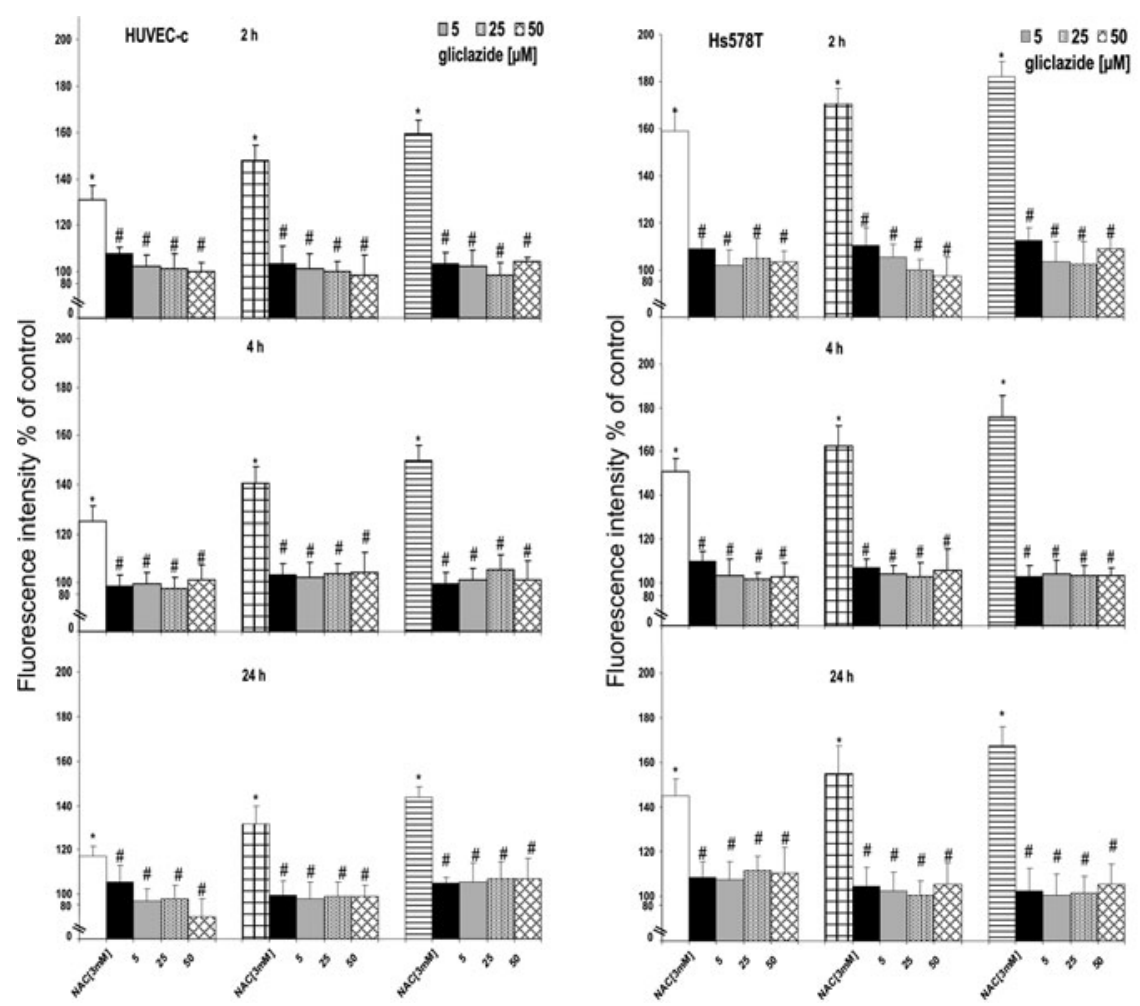

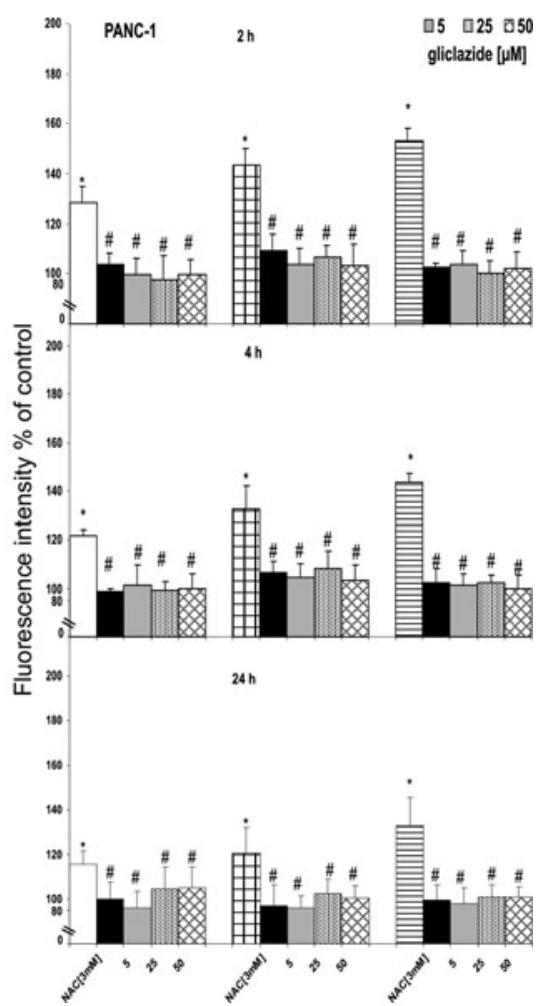

Fig. 2 Induction of ROS by $\mathrm{H}_{2} \mathrm{O}_{2}$ in HUVEC-c, Hs578T and PANC-1 cells in the presence and absence of NAC or gliclazide. The cells $\left(10^{4}\right)$, seeded into 96 -well microplates $24 \mathrm{~h}$ before the experiment were treated with different $\mathrm{H}_{2} \mathrm{O}_{2}$ concentrations for 2,4 or $24 \mathrm{~h}$. Oxidation of $5 \mu \mathrm{M}$ DCFH2-DA fluorescence probe was used for monitoring the produced ROS after drug treatment. In experiments with NAC or gliclazide, cells

mitochondrial membrane potential in HUVEC-c, Hs578T and PANC- 1 cells by $51 \%, 61$ and $69 \%$ respectively (Fig. 4 ) $(P \leq 0.05)$. The prolonged incubation $(4-24 \mathrm{~h})$ with the $\mathrm{H}_{2} \mathrm{O}_{2}$ led to an increase of mitochondrial membrane potential. The enhancement of $\Delta \Psi_{\mathrm{m}}$ to a level of control was observed at $24 \mathrm{~h}$ in all cell lines. NAC and gliclazide pretreatment effectively inhibited $\mathrm{H}_{2} \mathrm{O}_{2}$-induced loss of $\Delta \Psi_{\mathrm{m}}$ in all cell lines. Our results suggest that antioxidant action of gliclazide in therapeutic concentrations $(5-25 \mu \mathrm{M})$ was comparable to NAC. Interestingly, it was observed that higher concentrations of gliclazide evoked greater increase in mitochondrial membrane potential level in cancer cells than in normal human endothelial cells.

As a positive control, prior to JC-1 labeling, cells were preincubated with CCCP, a protonophoric uncoupler of oxidative phosphorylation, for the same period of time as that used for $\mathrm{H}_{2} \mathrm{O}_{2}$ treatment. The results are presented in Fig. 5. After $2 \mathrm{~h}$ incubation, $10 \mu \mathrm{M}$ CCCP caused loss of mitochondrial membrane potential in HUVEC-c, Hs578T, and PANC-1 cells up to 38,31 , and $49 \%$ respectively $(P \leq 0.05)$. We observed increase in $\Delta \Psi_{\mathrm{m}}$ at $4 \mathrm{~h}$ of incubation with $10 \mu \mathrm{M}$ CCCP: $49 \%$ for HUVEC-c, $47 \%$ for Hs578T, and 58\% for PANC-1 $(P \leq 0.05)$. In the longest were preincubated with $3 \mathrm{mM}$ NAC or 5-50 $\mu \mathrm{M}$ gliclazide for $1 \mathrm{~h}$, then $\mathrm{H}_{2} \mathrm{O}_{2}$ was added and incubation was continued for another 2,4 or $24 \mathrm{~h}$, The results represent mean $\pm \mathrm{SD}$ of four independent experiments, $* P<0.05$ in comparison to respective control cells taken as $100 \%$. ${ }^{\#} P<0.05$ indicates significant differences between $\mathrm{H}_{2} \mathrm{O}_{2}$-treated cells and samples preincubated with NAC or gliclazide

time of incubation ( $24 \mathrm{~h})$ with the $10 \mu \mathrm{M} \mathrm{CCCP}$ a gradual increase in $\Delta \Psi_{\mathrm{m}}$ was reported [60\% for HUVEC-c, $71 \%$ for Hs578T, and 68\% for PANC-1 $(P \leq 0.05)]$.

Morphological changes in $\mathrm{H}_{2} \mathrm{O}_{2}$ treated cell lines

The ability of $\mathrm{H}_{2} \mathrm{O}_{2}$ to induce apoptosis or necrosis was evaluated by treating the cells of each cell line with a concentration of $200 \mu \mathrm{M}$ for 24,48 or $72 \mathrm{~h}$. Analysis was performed immediately after $\mathrm{H}_{2} \mathrm{O}_{2}$ treatment. To assess the effect of $\mathrm{H}_{2} \mathrm{O}_{2}$ at the single cell level directly, we used fluorescence microscopy for examination of cells stained simultaneously with the membrane permeating and intercalating dye bisbenzimide Hoechst 33258 and propidium iodide. Changes in cell morphology, typical either of apoptosis or necrosis are presented in Fig. 6. Alterations in the structure, size and shape of the cell nucleus were detected 24, 48 and $72 \mathrm{~h}$ after the treatment with $\mathrm{H}_{2} \mathrm{O}_{2}$. The maximal increase in the amount of apoptotic cells was noted at $48 \mathrm{~h}$ of $\mathrm{H}_{2} \mathrm{O}_{2}$ treatment. After the prolonged incubation time $(72 \mathrm{~h})$ we observed chromatin condensation, cell shrinkage and nuclear fragmentation as well as a formation of apoptotic bodies. We reported that $\mathrm{H}_{2} \mathrm{O}_{2}$ 


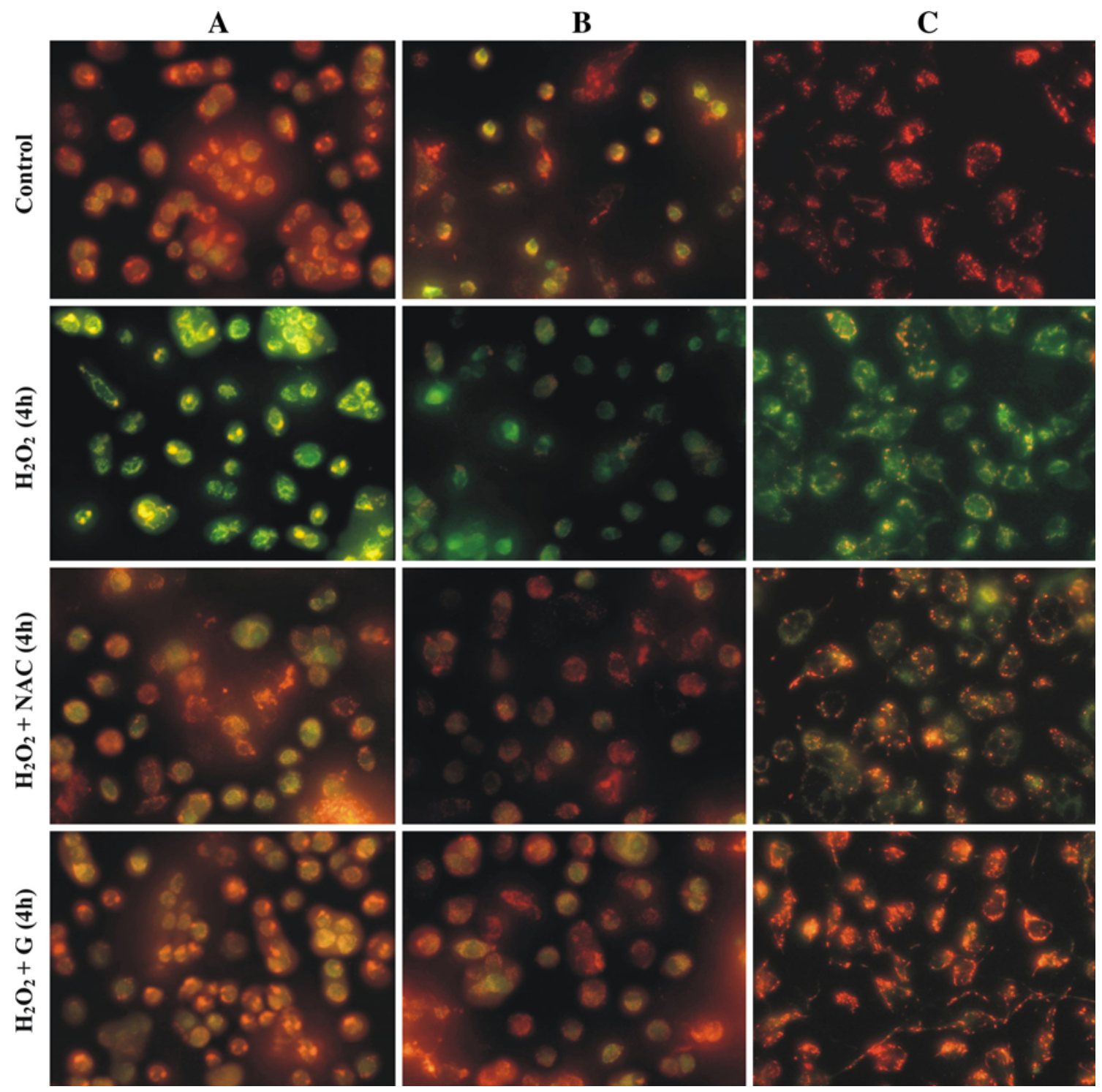

Fig. 3 Fluorescent microscopy images of a HUVEC-c, b Hs578T and c PANC- 1 cell lines at $4 \mathrm{~h}$ after $200 \mu \mathrm{M}$ of $\mathrm{H}_{2} \mathrm{O}_{2}$ treatment without or in the presence of NAC or gliclazide. In the experiments with the antioxidants the cells were preincubated with $25 \mu \mathrm{M}$ gliclazide or $3 \mathrm{mM} \mathrm{NAC}$ for $1 \mathrm{~h}$, then $\mathrm{H}_{2} \mathrm{O}_{2}$ was added and incubation was continued for the next $4 \mathrm{~h}$, mitochondria depolarization is indicated by a decrease in the red to green fluorescence

could induce both apoptosis and necrosis in the investigated cancer and normal cell lines. The number of apoptotic and necrotic cells were dependent on the time of incubation with $\mathrm{H}_{2} \mathrm{O}_{2}$ and the type of cell line. The considerable higher increase in the amount of necrotic cells was noted at $72 \mathrm{~h}$ after treatment of all tested cell lines with $\mathrm{H}_{2} \mathrm{O}_{2}$ (data not shown). The largest apoptotic changes were observed in HUVEC-c cell line. Pre-treatment of tested cells with the antioxidants, NAC or gliclazide partially reduced both apoptotic and necrotic cell population. It seems that gliclazide exhibit a similar protection intensity ratio, green fluorescence of JC-1 monomers is present in the cells areas with high mitochondrial membrane potential, while yellow-orange fluorescence of JC- dimers is prevalent in the cell areas with low mitochondrial membrane potential. The JC-1 stained cells were visualized under an inverted fluorescence microscope (Olympus IX70, Japan), 400× magnification. (Color figure online)

compared to NAC in relation to normal as well as cancer cells treated with $\mathrm{H}_{2} \mathrm{O}_{2}$.

Intracellular calcium ion concentration

To examine whether the intracellular calcium changes were involved in apoptosis induced by $\mathrm{H}_{2} \mathrm{O}_{2}$, we studied the level of calcium using the fluorescence probe Fluo- 4-NW. Our results indicate that calcium level also depends on $\mathrm{H}_{2} \mathrm{O}_{2}$ concentration, the time of incubation and the type of cells. Table 3 shows that in the tested cells $\mathrm{H}_{2} \mathrm{O}_{2}$ induced a 

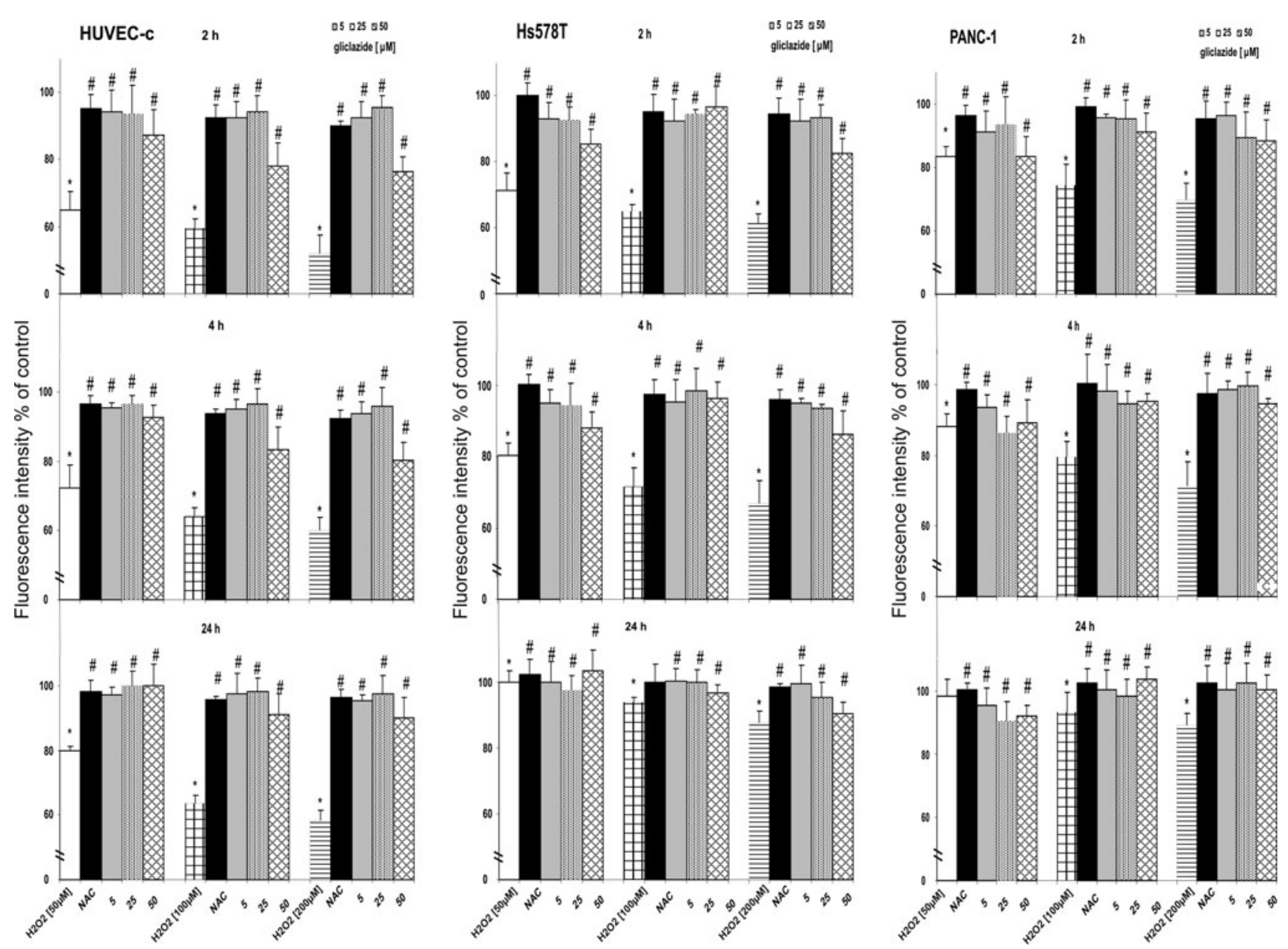

Fig. 4 Changes in mitochondrial membrane potential $\left(\Delta \Psi_{\mathrm{m}}\right)$ of HUVEC-c, Hs578T and PANC-1 cells seeded into black 96-well titration microplates in the presence and absence of antioxidant-NAC or gliclazide, The cells were treated with different $\mathrm{H}_{2} \mathrm{O}_{2}$ concentrations for 2, 4 or $24 \mathrm{~h}$. In experiments with antioxidant or gliclazide, cells were preincubated with $3 \mathrm{mM}$ NAC or $5-50 \mu \mathrm{M}$ gliclazide for $1 \mathrm{~h}$, then $\mathrm{H}_{2} \mathrm{O}_{2}$ was added and incubation was continued for another

2, 4 or 24 h. $\Delta \Psi_{\mathrm{m}}$ was estimated with a fluorescence dye JC-1 at the end of incubation directly in the cell monolayers. Fluorescence ratio of JC-1 dimers/JC-1 monomers of control was assumed as $100 \%$, The results represent mean $\pm \mathrm{SD}$ of four independent experiments. $* P<0.05$ in comparison to respective control cells taken as $100 \%$. ${ }^{\#} \mathrm{P}<0.05$ indicates significant differences between $\mathrm{H}_{2} \mathrm{O}_{2}$-treated cells and samples preincubated with NAC or gliclazide

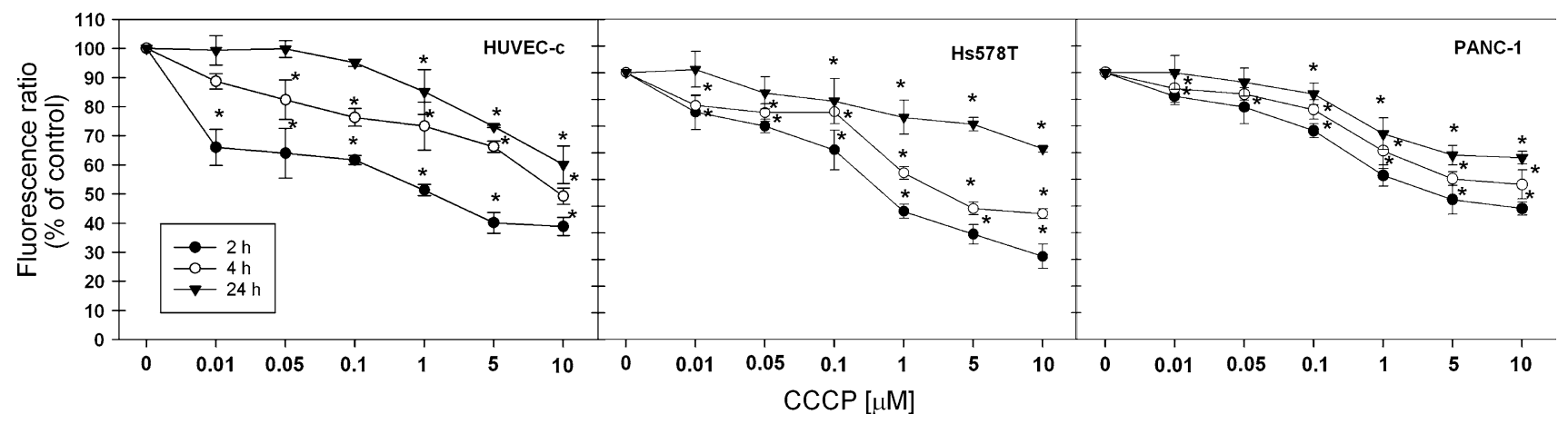

Fig. 5 Changes in mitochondrial membrane potential $\left(\Delta \Psi_{\mathrm{m}}\right)$ of HUVEC-c, Hs578T and PANC-1 cells incubated with CCCP for 2, 4 or $24 \mathrm{~h} . \Delta \Psi_{\mathrm{m}}$ was estimated with a fluorescence dye JC-1 directly in monolayers of cells seeded into black 96-well titration microplates.
Fluorescence ratio of JC- 1 dimers/JC-1 monomers of control was assumed as $100 \%$. Results are presented as mean \pm SD of 3-4 independent experiments. $* P<0.05$ in comparison to respective control cells taken as $100 \%$ 
A
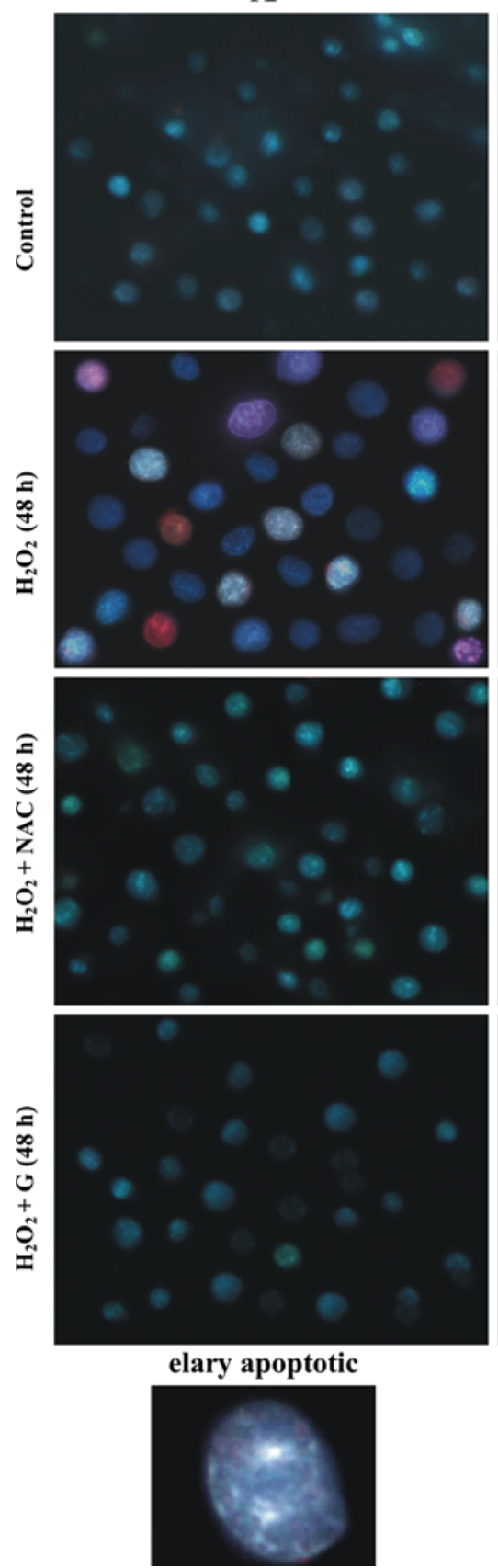

B
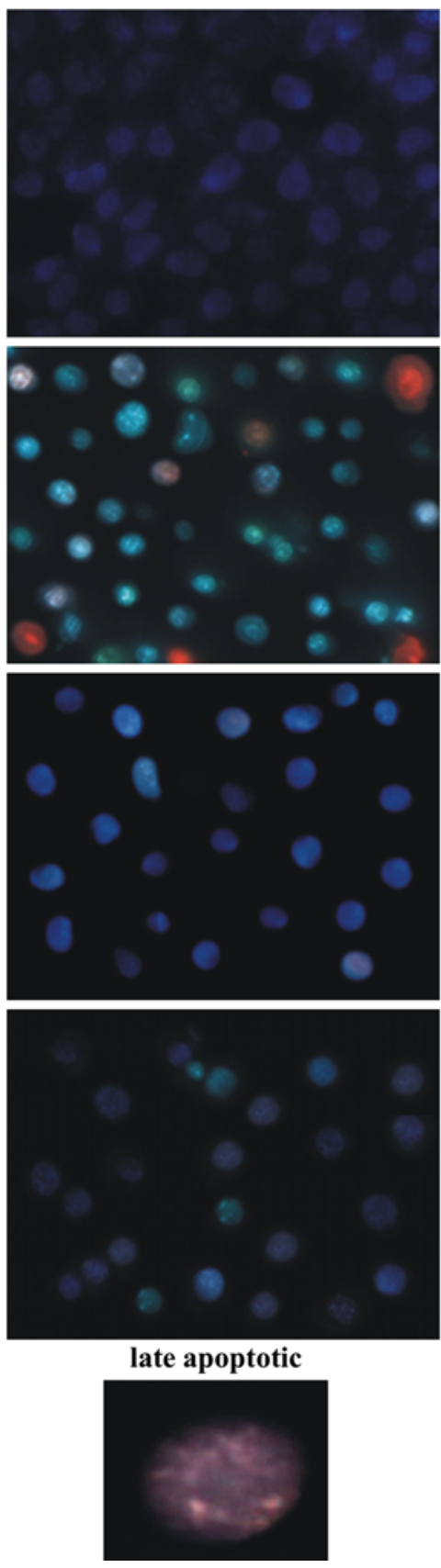

C
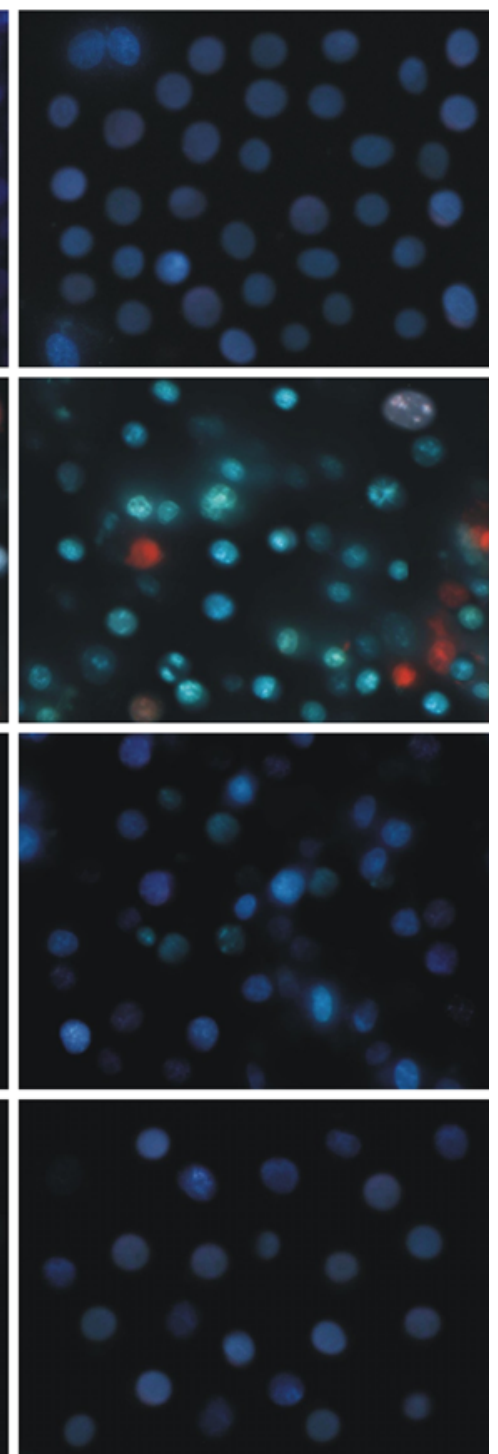

necrotic

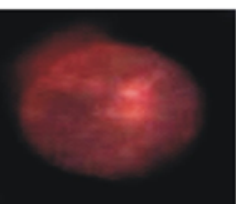

Fig. 6 Morphological changes of a HUVEC-c, b Hs578T and c PANC-1 cell lines at $48 \mathrm{~h}$ after $200 \mu \mathrm{M}$ of $\mathrm{H}_{2} \mathrm{O}_{2}$ treatment without or in the presence of antioxidants. The cells were stained with the PI and the DNA specific dye Hoechst 33258. In the experiments with the antioxidants the cells were preincubated with $25 \mu \mathrm{M}$ gliclazide or

significant increase in the intracellular free calcium no sooner than at $48 \mathrm{~h}$ of incubation. At this time point, the level of intracellular calcium in the HUVEC-c, Hs578T and PANC-1 cells, treated with $200 \mu \mathrm{M} \mathrm{H} \mathrm{H}_{2} \mathrm{O}_{2}$ increased by about 60,36 and $20 \%$, respectively $(P \leq 0.005)$. After $72 \mathrm{~h}$ incubation of the cells with $\mathrm{H}_{2} \mathrm{O}_{2}$ the level of calcium decreased in normal and cancer cells. The largest decrease
$3 \mathrm{mM}$ NAC for $1 \mathrm{~h}$, then $\mathrm{H}_{2} \mathrm{O}_{2}$ was added and incubation was continued for the next $48 \mathrm{~h}$. The cells were analyzed under an inverted fluorescence microscope (Olympus IX70, Japan) under magnification $400 \times$. (Color figure online)

in calcium content was noted in HUVEC-c cell line (about $37 \%)(P \leq 0.005)$ and the lowest in PANC-1 cells (about $14 \%)(P \leq 0.005)$ compared to the values at $48 \mathrm{~h}$ after the treatment. Free radical scavengers, NAC and gliclazide, significantly reduced $\mathrm{H}_{2} \mathrm{O}_{2}$-induced changes in calcium level at $48 \mathrm{~h}$ of incubation in all types of cells. At $72 \mathrm{~h}$, NAC and gliclazide markedly diminished $\mathrm{H}_{2} \mathrm{O}_{2}$-induced 
Table 3 Effect of $\mathrm{H}_{2} \mathrm{O}_{2}$ on intracellular level of $\mathrm{Ca}^{2+}$ in HUVEC-c, Hs578T and PANC-1 cells

\begin{tabular}{|c|c|c|c|c|}
\hline \multirow[t]{2}{*}{ Treatment time (h) } & \multirow[t]{2}{*}{ Agent } & \multicolumn{3}{|c|}{ Cell line ( $\%$ of viable cells) } \\
\hline & & HUVEC-c & HS578T & PANC-1 \\
\hline \multirow[t]{15}{*}{4} & $\mathrm{H}_{2} \mathrm{O}_{2}[50 \mu \mathrm{M}]$ & $102.22 \pm 2.39$ & $106.16 \pm 12.36$ & $102.36 \pm 13.69$ \\
\hline & NAC [3 mM] & $94.26 \pm 1.80$ & $98.30 \pm 4.58$ & $98.36 \pm 5.68$ \\
\hline & 5 & $99.06 \pm 0.01$ & $95.61 \pm 13.3^{\#}$ & $97.12 \pm 3.69$ \\
\hline & 25 gliclazide $[\mu \mathrm{M}]$ & $92.12 \pm 0.01$ & $100.98 \pm 1.25$ & $94.26 \pm 6.36$ \\
\hline & 50 & $104.18 \pm 2.70$ & $97.37 \pm 1.69$ & $93.45 \pm 4.52$ \\
\hline & $\mathrm{H}_{2} \mathrm{O}_{2}[100 \mu \mathrm{M}]$ & $102.07 \pm 3.58$ & $99.22 \pm 2.58$ & $101.36 \pm 3.35$ \\
\hline & NAC [3 mM] & $91.20 \pm 1.36$ & $92.93 \pm 4.69$ & $102.36 \pm 1.23$ \\
\hline & 5 & $107.72 \pm 5.12$ & $87.19 \pm 1.2 \mathrm{~S}$ & $96.36 \pm 3.69$ \\
\hline & 25 gliclazide $[\mu \mathrm{M}]$ & $103.19 \pm 0.04$ & $94.78 \pm 4.58$ & $99.26 \pm 3.36$ \\
\hline & 50 & $104.65 \pm 5.54$ & $91.91 \pm 3.69$ & $93.65 \pm 1.58$ \\
\hline & $\mathrm{H}_{2} \mathrm{O}_{2}[200 \mu \mathrm{M}]$ & $98.44 \pm 4.12$ & $98.00 \pm 2.58$ & $103.24 \pm 1.58$ \\
\hline & NAC $[3 \mathrm{mM}]$ & $103.27 \pm 3.25$ & $96.54 \pm 5.59$ & $102.53 \pm 3.69$ \\
\hline & 5 & $105.93 \pm 2.00$ & $90.89 \pm 3.69$ & $100.36 \pm 2.58$ \\
\hline & 25 gliclazide $[\mu \mathrm{M}]$ & $100.67 \pm 4.04$ & $87.00 \pm 4.69$ & $96.36 \pm 2.98$ \\
\hline & 50 & $100.93 \pm 1.04$ & $93.11 \pm 6.54$ & $97.89 \pm 5.45$ \\
\hline \multirow[t]{15}{*}{24} & $\mathrm{H}_{2} \mathrm{O}_{2}[50 \mu \mathrm{M}]$ & $94.79 \pm 1.25$ & $85.11 \pm 2.45$ & $92.36 \pm 1.23$ \\
\hline & NAC [3 mM] & $98.35 \pm 2.36$ & $90.13 \pm 1.22$ & $98.12 \pm 2.36$ \\
\hline & 5 & $92.12 \pm 0.01$ & $103.02 \pm 372$ & $101.32 \pm 4.39$ \\
\hline & 25 gliclazide $[\mu \mathrm{M}]$ & $100.98 \pm 2.6$ & $103.70 \pm 2.48$ & $100.31 \pm 1.58$ \\
\hline & 50 & $100.59 \pm 3.42$ & $98.26 \pm 1.54$ & $100.01 \pm 6.67$ \\
\hline & $\mathrm{H}_{2} \mathrm{O}_{2}[100 \mu \mathrm{M}]$ & $95.24 \pm 2.36$ & $90.85 \pm 2.43$ & $102.53 \pm 1.36$ \\
\hline & NAC [3 mM] & $104.78 \pm 1.25$ & $93.98 \pm 1.42$ & $103.21 \pm 2.25$ \\
\hline & 5 & $96.59 \pm 0.03$ & $109.41 \pm 0.82$ & $99.87 \pm 6.65$ \\
\hline & 25 gliclazide $[\mu \mathrm{M}]$ & $106.77 \pm 6.56$ & $106.11 \pm 1.37$ & $101.3 \pm 6.64$ \\
\hline & 50 & $104.04 \pm 7.37$ & $92.60 \pm 1.3$ & $103.65 \pm 2.64$ \\
\hline & $\mathrm{H}_{2} \mathrm{O}_{2}[200 \mu \mathrm{M}]$ & $98.21 \pm 2.36$ & $91.73 \pm 1.33$ & $101.23 \pm 1.36$ \\
\hline & NAC [3 mM] & $106.77 \pm 1.36$ & $94.54 \pm 2.34$ & $99.87 \pm 554$ \\
\hline & 5 & $96.78 \pm 5.23$ & $100.32 \pm 1.51$ & $102.36 \pm 6.36$ \\
\hline & 25 gliclazide $[\mu \mathrm{M}]$ & $102.52 \pm 7.43$ & $102.10 \pm 0.77$ & $100.32 \pm 1.36$ \\
\hline & 50 & $106.30 \pm 4.21$ & $112.51 \pm 1.48$ & $100.02 \pm 5.23$ \\
\hline \multirow[t]{15}{*}{48} & $\mathrm{H}_{2} \mathrm{O}_{2}[50 \mu \mathrm{M}]$ & $122.65 \pm 2.36^{*}$ & $110.23 \pm 1.36$ & $108.23 \pm 2.36$ \\
\hline & NAC [3 mM] & $107.91 \pm 2.54^{\#}$ & $96.26 \pm 2.58^{\#}$ & $102.32 \pm 5.54$ \\
\hline & 5 & $100.27 \pm 4.58^{\#}$ & $101.13 \pm 3.65$ & $99.36 \pm 6.32$ \\
\hline & 25 gliclazide $[\mu \mathrm{M}]$ & $100.41 \pm 4.96^{\#}$ & $104.81 \pm 3.05$ & $98.36 \pm 6.14$ \\
\hline & 50 & $102.68 \pm 5.63^{\#}$ & $104.81 \pm 5.28$ & $95.3 \pm 1.25$ \\
\hline & $\mathrm{H}_{2} \mathrm{O}_{2}[100 \mu \mathrm{M}]$ & $139.67 \pm 6.54 *$ & $125.48 \pm 3.69^{*}$ & $113.25 \pm 5.87^{*}$ \\
\hline & NAC [3 mM] & $106.3 \mathrm{~S} \pm 7.41^{\#}$ & $97.24 \pm 5.40^{\#}$ & $98.36 \pm 7.87^{\#}$ \\
\hline & 5 & $100.98 \pm 2.65^{\#}$ & $98.45 \pm 6.36^{\#}$ & $97.54 \pm 5.69^{\#}$ \\
\hline & 25 gliclazide $[\mu \mathrm{M}]$ & $10086 \pm 6.32^{\#}$ & $99.12 \pm 3.36^{\#}$ & $94.15 \pm 4.12^{\#}$ \\
\hline & 50 & $95.37 \pm 4.12^{\#}$ & $92.41 \pm 1.25^{\#}$ & $93.65 \pm 6.48^{\#}$ \\
\hline & $\mathrm{H}_{2} \mathrm{O}_{2}[200 \mu \mathrm{M}]$ & $159.57 \pm 1.23^{*}$ & $135.56 \pm 1.25^{*}$ & $120.36 \pm 12.54^{*}$ \\
\hline & $\mathrm{NAC}[3 \mathrm{mM}]$ & $101.15 \pm 6.54^{\#}$ & $100.10 \pm 2.23^{\#}$ & $102.53 \pm 4.38^{\#}$ \\
\hline & 5 & $112.52 \pm 6.32^{\#}$ & $91.00 \pm 12.57^{\#}$ & $102.36 \pm 8.58^{\#}$ \\
\hline & 25 gliclazide $[\mu \mathrm{M}]$ & $103.95 \pm 4.52^{\#}$ & $94.64 \pm 6.32^{\#}$ & $98.26 \pm 6.36^{\#}$ \\
\hline & 50 & $111.49 \pm 4.23^{\#}$ & $92.88 \pm 6.54^{\#}$ & $98.64 \pm 554^{\#}$ \\
\hline
\end{tabular}


Table 3 continued

\begin{tabular}{|c|c|c|c|c|}
\hline \multirow[t]{2}{*}{ Treatment time (h) } & \multirow[t]{2}{*}{ Agent } & \multicolumn{3}{|c|}{ Cell line (\% of viable cells) } \\
\hline & & HUVEC-c & HS578T & PANC-1 \\
\hline \multirow[t]{15}{*}{72} & $\mathrm{H}_{2} \mathrm{O}_{2}[50 \mu \mathrm{M}]$ & $108.68 \pm 2.36$ & $104.36 \pm 1.23$ & $103.36 \pm 3.65$ \\
\hline & NAC [3 mM] & $95.39 \pm 1.54$ & $102.92 \pm 3.36$ & $102.53 \pm 4.21$ \\
\hline & 5 & $10553 \pm 6.36$ & $92.31 \pm 3.65$ & $98.65 \pm 5.36$ \\
\hline & 25 gliclazide $[\mu \mathrm{M}]$ & $103.15 \pm 4.23$ & $97.15 \pm 1.25$ & $96.32 \pm 4.65$ \\
\hline & 50 & $102.26 \pm 6.36$ & $104.29 \pm 3.164$ & $92.36 \pm 6.32$ \\
\hline & $\mathrm{H}_{2} \mathrm{O}_{2}[100 \mu \mathrm{M}]$ & $113.32 \pm 1.54^{*}$ & $97.91 \pm 3.65$ & $105.36 \pm 8.12$ \\
\hline & NAC [3 mM] & $100.32 \pm 16.36^{\#}$ & $102.56 \pm 5.14$ & $98.26 \pm 6.54$ \\
\hline & 5 & $98.261 \pm 4.58^{\#}$ & $104.94 \pm 4.87$ & $96.54 \pm 7.26$ \\
\hline & 25 gliclazide $[\mu \mathrm{M}]$ & $97.50 \pm 6.32^{\#}$ & $100.42 \pm 5.87$ & $93.25 \pm 5.21$ \\
\hline & 50 & $95.65 \pm 1.25^{\#}$ & $101.73 \pm 4.56$ & $91.25 \pm 1.36$ \\
\hline & $\mathrm{H}_{2} \mathrm{O}_{2}[200 \mu \mathrm{M}]$ & $123.53 \pm 1.36^{*}$ & $111.23 \pm 2.36^{*}$ & $106.32 \pm 2.54$ \\
\hline & NAC [3 mM] & $105.32 \pm 2.64^{\#}$ & $110.87 \pm 3.65$ & $102.51 \pm 4.65$ \\
\hline & 5 & $102.26 \pm 4.65^{\#}$ & $97.73 \pm 4.58^{\#}$ & $99.36 \pm 6.58$ \\
\hline & 25 gliclazide $[\mu \mathrm{M}]$ & $105.50 \pm 3.60^{\#}$ & $86.39 \pm 9.65^{\#}$ & $95.36 \pm 2.65$ \\
\hline & 50 & $101.67 \pm 5.45^{\#}$ & $95.43 \pm 4.58^{\#}$ & $97.12 \pm 6.32$ \\
\hline
\end{tabular}

The cells were treated with different $\mathrm{H}_{2} \mathrm{O}_{2}$ concentrations for $4,24,48$ or $72 \mathrm{~h}$. In experiments with antioxidant or gliclazide, cells were preincubated with $3 \mathrm{mM} \mathrm{NAC}$ or 5-50 $\mu \mathrm{M}$ gliclazide for $1 \mathrm{~h}$, then $\mathrm{H}_{2} \mathrm{O}_{2}$ was added and incubation was continued for another 4, 24, 48 or $72 \mathrm{~h}$. The results represent mean $\pm \mathrm{SD}$ of four independent experiments. ${ }^{*} P<0.05$ in comparison to respective control cells taken as $100 \%$, ${ }^{\#} P<0.05$ indicates significant differences between $\mathrm{H}_{2} \mathrm{O}_{2}$-treated cells and samples preincubated with NAC or gliclazide

$(100,200 \mu \mathrm{M})$ changes in calcium level in normal cells $(P \leq 0.05)$. Only in Hs578T cells changes in calcium level induced by $200 \mu \mathrm{M} \mathrm{H} \mathrm{H}_{2} \mathrm{O}_{2}$ after $72 \mathrm{~h}$ of incubation were markedly diminished by gliclazide.

In summary, $\mathrm{H}_{2} \mathrm{O}_{2}$ caused a significant increase in intracellular calcium levels after $48 \mathrm{~h}$. Moreover, at the same time the greatest apoptotic changes were observed (Fig. 6). The ROS generation was observed already at $2 \mathrm{~h}$ of $\mathrm{H}_{2} \mathrm{O}_{2}$ incubation. Our results indicate that ROS evoked increased level of calcium. Pre-incubation with antioxidants: NAC and gliclazide effectively decreased $\mathrm{H}_{2} \mathrm{O}_{2}$ induced ROS enhancement and diminished an increase of cytoplasmic free calcium in all cell lines.

\section{Discussion}

It is well known that T2DM generally progresses over time and majority of diabetics previously well-metabolically controlled with sulfonylureas may require insulin replacement therapy. It has been suggested that exhaustion or desensitization of pancreatic $\beta$-cells by prolonged exposure to sulphonylureas and possibly acceleration of oxidative stress and apoptosis are major causes of secondary failure to these oral hypoglycemic medications. The association of glibenclamide with increased $\beta$-cell apoptosis in human islets has been demonstrated in vitro by Meadler et al. [25]. Clinical studies indicate that early insulin treatment in newly diagnosed T2DM patients preserved $\beta$-cell secretory function more effectively than glibenclamide [26]. Interestingly, a retrospective analysis performed by Satoh et al. found that patients treated with gliclazide required exogenous insulin support less frequently, than those treated with glibenclamide. These observations suggest that gliclazide but not glibenclamide may protect $\beta$-cells and thereby delay development of a secondary failure [27]. It is worth mentioning that gliclazide may protect against oxidative stress-related diabetic complications since a significantly lower mortality for cardiovascular diseases and malignancies was suggested in patients treated with gliclazide compared to other hypoglycaemic drugs, especially sulphonylureas [28-30].

There are several mechanisms that may be responsible for $\beta$-cell mass loss and dysfunction associated with sulfonylureas use in diabetics. ROS overproduction and disequilibrium of $\mathrm{Ca}^{2+}$ homeostasis induced by sulfonylureas seem to be involved in these processes. It was demonstrated that glibenclamide, glimepiride and nateglinide stimulate ROS production in the pancreatic $\beta$-cell line MIN6 within the therapeutic concentration range in plasma of treated patients $[12,31]$. Sawada et al. have found that these compounds-related ROS production was mediated by a PKC-dependent activation of $\mathrm{NAD}(\mathrm{P}) \mathrm{H}$ oxidase [12]. The secreatgogues raise the intracellular $\mathrm{Ca}^{2+}$ concentration by opening of voltage-operated $\mathrm{Ca}^{2+}$ channels and increasing $\mathrm{Ca}^{2+}$ influx [32]. Since $\mathrm{Ca}^{2+}$ plays an important 
role in cell survival regulation, the significant increase in the intracellular $\mathrm{Ca}^{2+}$ concentration induced by glibenclamide or tolbutamide may initiate $\mathrm{Ca}^{2+}$ dependent $\beta$-cell apoptosis [33, 34].

In our experiments, we used $\mathrm{H}_{2} \mathrm{O}_{2}$ which by generation of ROS increases an oxidative stress insult that may cause cells death [35]. Number of evidence indicates that $\mathrm{H}_{2} \mathrm{O}_{2}$ / ROS activate $\mathrm{K}_{\mathrm{ATP}}^{+}$channels and hyperpolarize the plasma membrane potential. It has been reported that an oxidative stress potentates the amount of ROS by stimulating mitochondrial ROS production. ROS are also able to trigger the opening of the mitochondrial permeability transition pore to an extent, that collapses the mitochondrial membrane potential and leads to ATP depletion [15, 36, 37]. Moreover, a reduction in the mitochondrial membrane potential $\left(\Delta \Psi_{\mathrm{m}}\right)$ results in the release of mitochondrial $\mathrm{Ca}^{2+}$ and a rise in cytosolic $\left[\mathrm{Ca}^{2+}\right]$ and may also contribute to cell death [38, 39].

As we expected, $\mathrm{H}_{2} \mathrm{O}_{2}$ induced apoptosis in human normal and cancer cells since the cytotoxic effects of this molecule is well known [40]. The results of our study indicate that gliclazide reduced the number of $\mathrm{H}_{2} \mathrm{O}_{2}$-related necrotic and apoptotic cells. These findings are consistent with the earlier reports showing, that gliclazide attenuated apoptotic $\beta$-cell as well as endothelial cells death induced by an oxidative stress. As was suggested by others, we believe that this effect is most likely caused by free radical scavenging properties of gliclazide [15-18]. It is worth underlying that these unique activities of the drug are not shared by other sulphonylureas [20, 41]. Recently, it has been reported that glibenclamide and glimepiride, but not gliclazide, significantly increased ROS production in $\beta$-cell [12]. It is suggested that several mechanisms may be responsible for these differences. Firstly, gliclazide possesses free radical scavenging activity. Secondly, the binding of gliclazide to SUR1 receptor is rapidly reversible in contrary to other sulphonylureas [10, 42]. Finally, Gier et al. have found that gliclazide may up-regulate the expression of antioxidant enzymes (superoxide dismutase, glutathione peroxidase, catalase). Their experiments demonstrated that enzyme activity changes in pancreatic $\beta$-cells were dependent on $\left[\mathrm{Ca}^{2+}\right]$ mediated via $\mathrm{K}_{\mathrm{ATP}}$ channels [15]. Interestingly, the results of our study may at least partially support these findings because we showed that gliclazide decreased the intracellular $\left[\mathrm{Ca}^{2+}\right]$ in tested cell lines exposed to $\mathrm{H}_{2} \mathrm{O}_{2}$.

Mitochondria are major intracellular source of reactive oxygen species and play an important role in apoptotic form of cell death [43]. As was mentioned earlier, $\mathrm{ROS} / \mathrm{H}_{2} \mathrm{O}_{2}$ cause depolarization of mitochondria and local $\mathrm{Ca}^{2+}$ release, what leads to loss of $\Delta \Psi_{\mathrm{m}}$, opening of mitochondrial permeability transition pore, damage to cell and finally cell death $[39,44]$. This effect of $\mathrm{H}_{2} \mathrm{O}_{2}$ was confirmed in our experiments. We observed significant loss of $\Delta \Psi_{\mathrm{m}}$ in all kind of cells as early as after $2 \mathrm{~h}$ of exposure to $\mathrm{H}_{2} \mathrm{O}_{2}$. Furthermore, we have observed an increase in the intracellular free $\left[\mathrm{Ca}^{2+}\right]$ in $\mathrm{H}_{2} \mathrm{O}_{2}$-treated human normal and cancer cell lines at $48 \mathrm{~h}$ of incubation. The accumulation of fluorescent dye JC-1 in mitochondria as a consequence of changes in $\Delta \Psi_{\mathrm{m}}$ after treatment with $\mathrm{H}_{2} \mathrm{O}_{2}$ was also noted. These findings are in agreement with previous observations [36, 44, 45]. Nakazaki et al. found, that in rat pancreatic $\beta$-cells $\mathrm{H}_{2} \mathrm{O}_{2}$ led to an increase in intracellular $\left[\mathrm{Ca}^{2+}\right]$ due to its release from cytosolic stores and increase in $\mathrm{Ca}^{2+}$ influx across the plasma membrane (through L-type $\mathrm{Ca}^{2+}$ channels) [36]. Gonzalez et al. reported that $\mathrm{H}_{2} \mathrm{O}_{2}$ caused loss of $\Delta \Psi_{\mathrm{m}}$ and an increase in intracellular $\left[\mathrm{Ca}^{2+}\right]$ in isolated mouse pancreatic acinar cells [46]. The results of our experiments showed that pre-treatment with gliclazide effectively inhibits $\mathrm{H}_{2} \mathrm{O}_{2}$-induced loss of mitochondrial membrane potential and significantly decreases the level of intracellular $\left[\mathrm{Ca}^{2+}\right]$ in tested cell lines.

Recently, it was reported that the oxidative stress and $\mathrm{Ca}^{2+}$ homeostasis are associated with endoplasmic reticulum stress (ER stress) [47]. Marchetti et al. found that both ER stress and oxidative stress may play a prominent role in $\beta$-cell apoptosis evoked by high glucose concentration in islets isolated from diabetic patients [48]. Since we noted, that gliclazide decreased the intracellular $\left[\mathrm{Ca}^{2+}\right]$ in $\mathrm{H}_{2} \mathrm{O}_{2}$ treated cell lines, it cannot be excluded, that the drug may protect from apoptosis not only via decreasing the level of oxidative stress, but also the level of ER stress.

In summary, the results of our work provide an additional evidence that gliclazide may diminish oxidative stress-related cell damage and death. Gliclazide decreases ROS production, elevates $\Delta \Psi_{\mathrm{m}}$ and diminishes intracellular $\left[\mathrm{Ca}^{2+}\right]$ in human normal and cancer cells exposed to $\mathrm{H}_{2} \mathrm{O}_{2}$. However, further studies are needed to explore whether the same effect occurs in T2DM patients treated with this drug.

Acknowledgments This work was supported by the grant from the Polish Society of Metabolic Disease and by the grants 503-0077-9 and 502-04-007 from Medical University of Lodz.

Open Access This article is distributed under the terms of the Creative Commons Attribution Noncommercial License which permits any noncommercial use, distribution, and reproduction in any medium, provided the original author(s) and source are credited.

\section{References}

1. Rahier J, Guiot Y, Goebbels RM, Sempoux C, Henquin JC (2008) Pancreatic beta-cell mass in European subjects with type 2 diabetes. Diabetes Obes Metab 10(Suppl 4):32-42

2. Prentki M, Nolan CJ (2006) Islet beta cell failure in type 2 diabetes. J Clin Invest 116:1802-1812 
3. Donath MY, Böni-Schnetzler M, Ellingsgaard H, Ehses JA (2009) Islet inflammation impairs the pancreatic beta-cell in type 2 diabetes. Physiology (Bethesda) 24:325-331

4. Robertson RP, Harmon J, Tran PO, Poitout V (2004) Beta-cell glucose toxicity, lipotoxicity, and chronic oxidative stress in type 2 diabetes. Diabetes 53(Suppl 1):S119-S124

5. Evans JL, Goldfine ID, Maddux BA, Grodsky GM (2002) Oxidative stress and stress-activated signaling pathways: a unifying hypothesis of type 2 diabetes. Endocr Rev 23:599-622

6. Robertson RP, Harmon J, Tran PO, Tanaka Y, Takahashi H (2003) Glucose toxicity in $\beta$-cells: type 2 diabetes, good radicals gone bad, and the glutathione connection. Diabetes 52:581-587

7. Brownlee M (2001) Biochemistry and molecular cell biology of diabetic complications. Nature 414:813-820

8. Rustenbeck I, Baltrusch S, Tiedge M (2010) Do insulinotropic glucose-lewering drugs do more harm than good? The hypersecretion hypothesis revisited. Diabetologia 53:2105-2111

9. Krentz AJ, Bailey CJ (2005) Oral antidiabetic agents: current role in type 2 diabetes mellitus. Drugs 65:385-411

10. Jennings PE (2000) Vascular benefits of gliclazide beyond glycemic control. Metabolism 49:17-20

11. Fava D, Cassone-Faldetta M, Laurenti O, De Luca O, Ghiselli A, De Mattia G (2002) Gliclazide improves anti-oxidant status and nitric oxide-mediated vasodilation in type 2 diabetes. Diabet Med 19:752-757

12. Sawada F, Inoguchi T, Tsubouchi $\mathrm{H}$ et al (2008) Differential effect of sulfonylureas on production of reactive oxygen species and apoptosis in cultured pancreatic beta-cell line, MIN6. Metabolism 57:1038-1045

13. Lortz S, Gurgul-Convey E, Lenzen S, Tiedge M (2005) Importance of mitochondrial superoxide dismutase expression in insulin-producing cells for the toxicity of reactive oxygen species and proinflammatory cytokines. Diabetologia 48:1541-1548

14. Eizirik DL, Cardozo AK, Cnop M (2008) The role for endoplasmic reticulum stress in diabetes mellitus. Endocr Rev 29:42-61

15. Gier B, Krippeit-Drews P, Sheiko T et al (2009) Suppression of KATP channel activity protects murine pancreatic beta cells against oxidative stress. J Clin Invest 119:3246-3256

16. Li L, Renier G (2009) The oral anti-diabetic agent, gliclazide, inhibits oxidized LDL-mediated LOX-1 expression, metalloproteinase-9 secretion and apoptosis in human aortic endothelial cells. Atherosclerosis 204:40-46

17. Corgnali M, Piconi L, Ihnat M, Ceriello A (2008) Evaluation of gliclazide ability to attenuate the hyperglycaemic 'memory' induced by high glucose in isolated human endothelial cells. Diabetes Metab Res Rev 24:301-309

18. Del Guerra S, Grupillo M, Masini M et al (2007) Gliclazide protects human islet beta-cells from apoptosis induced by intermittent high glucose. Diabetes Metab Res Rev 23:234-238

19. Kimoto K, Suzuki K, Kizaki T et al (2003) Gliclazide protects pancreatic beta-cells from damage by hydrogen peroxide. Biochem Biophys Res Commun 303:112-119

20. Noda Y, Mori A, Cossins E, Packer L (2000) Gliclazide scavenges hydroxyl and superoxide radicals: an electron spin resonance study. Metabolism 49(2 Suppl 1):14-16

21. Carmichael J, DeGraff WG, Gazdar AF, Minna JD, Mitchell JB (1987) Evaluation of a tetrazolium-based semiautomated colorimetric assay: assessment of radiosensitivity. Cancer Res 47:943-946

22. Nuydens R, Novalbos J, Dispersyn G, Weber C, Borgers M, Geerts H (1999) A rapid method for the evaluation of compounds with mitochondria-protective properties. J Neurosci Meth 92:153-159

23. Gasiorowski K, Brokos B, Kulma A, Ogorzałek A, Skórkowska K (2001) A comparison of the methods applied to detect apoptosis in genotoxically-damaged lymphocytes cultured in the presence of four antimutagens. Cell Mol Biol Lett 6:141-159
24. Burkitt MJ, Wardman $\mathrm{P}$ (2001) Cytochrome $C$ is a potent catalyst of dichlorofluorescin oxidation: implications for the role of reactive oxygen species in apoptosis. Biochem Biophys Res Commun 282:329-333

25. Maedler K, Carr RD, Bosco D, Zuellig RA, Berney T, Donath MY (2005) Sulfonylurea induced beta-cell apoptosis in cultured human islets. J Clin Endocrinol Metab 90:501-506

26. Alvarsson M, Sundkvist G, Lager I et al (2003) Beneficial effects of insulin versus sulphonylurea on insulin secretion and metabolic control in recently diagnosed type 2 diabetic patients. Diabetes Care 26:2231-2237

27. Satoh J, Takahashi K, Takizawa Y et al (2005) Secondary sulfonylurea failure: comparison of period until insulin treatment between diabetic patients treated with gliclazide and glibenclamide. Diabetes Res Clin Pract 70:291-297

28. Monami M, Balzi D, Lamanna C, Barchielli A, Masotti G, Buiatti E, Marchionni N, Manucci E (2007) Are sulphonylureas all the same? A cohort study on cardiovascular and cancer-related mortality. Diabetes Metab Res Rev 23(2007):479-484

29. Monami M, Lamanna C, Balzi D, Marchionni N, Mannucci E (2009) Sulphonylureas and cancer: a case-control study. Acta Diabetol 46:279-284

30. Horsdal HT, Johnsen SP, Søndergaard F, Jacobsen J, Thomsen RW, Schmitz O, Sørensen HT, Rungby J (2009) Sulfonylureas and prognosis after myocardial infarction in patients with diabetes: a population-based follow-up study. Diabetes Metab Res Rev 25:515-522

31. Tsubouchi H, Inoguchi T, Inuo M et al (2005) Sulfonylurea as well as elevated glucose levels stimulate reactive oxygen species production in the pancreatic beta-cell line, MIN6-a role of NAD $(\mathrm{P}) \mathrm{H}$ oxidase in beta-cells. Biochem Biophys Res Commun 326:60-65

32. Dufer M, Haspel D, Krippeit-Drews P et al (2007) KATP channel is critical for calcium sequestration into non-ER compartments in mouse pancreatic beta cells. Cell Physiol Biochem 20:65-74

33. Demaurex N, Distelhorst C, Cell biology (2003) Apoptosis-the calcium connection. Science 300:65-67

34. Iwakura T, Fujimoto S, Kagimoto S et al (2000) Sustained enhancement of $\mathrm{Ca}(2+)$ influx by glibenclamide induces apoptosis in RINm5F cells. Biochem Biophys Res Commun 271:422-428

35. Cross CE, Halliwell B, Borish ET et al (1987) Oxygen radicals and human disease. Ann Intern Med 107:526-545

36. Nakazaki M, Kakei M, Yaekura K et al (2000) Diverse effects of hydrogen peroxide on cytosolic $\mathrm{Ca}^{2+}$ homeostasis in rat pancreatic beta-cells. Cell Struct Funct 25:187-193

37. Zorov DB, Juhaszova M, Sollott SJ (2006) Mitochondrial ROSinduced ROS release: an update and review. Biochim Biophys Acta 1757:509-517

38. Pariente JA, Camello C, Camello PJ, Salido GM (2001) Release of calcium from mitochondrial and nonmitochondrial intracellular stores in mouse pancreatic acinar cells by hydrogen peroxide. J Membr Biol 179:27-35

39. Jacobson J, Duchen MR (2002) Mitochondrial oxidative stress and cell death in astrocytes-requirement for stored $\mathrm{Ca}^{2+}$ and sustained opening of the permeability transition pore. J Cell Sci 115:1175-1188

40. Bae JY, Ahn SJ, Han W, Noh DY (2007) Peroxiredoxin I and II inhibit $\mathrm{H}_{2} \mathrm{O}_{2}$-induced cell death in MCF-7 cell lines. J Cell Biochem 101:1038-1045

41. Scott NA, Jennings PE, Brown J, Belch JJ (1991) Gliclazide: a general free radical scavenger. Eur J Pharmacol 208:175-177

42. Gribble FM, Reimann F (2003) Differential selectivity of insulin secretagogues: mechanisms, clinical implications, and drug interactions. J Diabetes Complicat 17(2 Suppl):11-15

43. Orrenius S (2007) Reactive oxygen species in mitochondriamediated cell death. Drug Metab Rev 39:443-455 
44. Duchen MR (2000) Mitochondria and calcium: from cell signalling to cell death. J Physiol 1:57-68

45. Choi SE, Min SH, Shin HC, Kim HE, Jung MW, Kang Y (2006) Involvement of calcium-mediated apoptotic signals in $\mathrm{H}_{2} \mathrm{O}_{2}$ induced MIN6N8a cell death. Eur J Pharmacol 547:1-9

46. González A, Granados MP, Salido GM, Pariente JA (2005) $\mathrm{H}_{2} \mathrm{O}_{2^{-}}$ induced changes in mitochondrial activity in isolated mouse pancreatic acinar cells. Mol Cell Biochem 269:165-173
47. Casas S, Novials A, Reimann F, Gomis R, Gribble FM (2008) Calcium elevation in mouse pancreatic beta cells evoked by extracellular human islet amyloid polypeptide involves activation of the mechanosensitive ion channel TRPV4. Diabetologia 51:2252-2262

48. Marchetti P, Bugliani M, Lupi R et al (2007) The endoplasmic reticulum in pancreatic beta cells of type 2 diabetes patients. Diabetologia 50:2486-2494 